\title{
Insights to plant-microbe interactions provide opportunities to improve resistance breeding against root diseases in grain legumes
}

\author{
Lukas Wille $^{1,2}$ | Monika M. Messmer ${ }^{1}$ (i) । Bruno Studer ${ }^{2}$ । Pierre Hohmann ${ }^{1}$
}

${ }^{1}$ Department of Crop Sciences, Research Institute of Organic Agriculture (FiBL), 5070 Frick, Switzerland

${ }^{2}$ Molecular Plant Breeding, Institute of Agricultural Sciences, ETH Zürich, 8092 Zurich, Switzerland

\section{Correspondence}

Pierre Hohmann, Department of Crop Sciences, Research Institute of Organic Agriculture (FiBL), 5070 Frick, Switzerland. Email: pierre.hohmann@fibl.org

\section{Funding information}

Project "resPEAct", World Food System Center and Mercator Foundation Switzerland; Project LIVESEED, Horizon 2020 Societal Challenges, Grant/Award Number: 727230; Swiss State Secretariat for Education, Research and Innovation, Grant/Award Number: SERI, 17.00090; Swiss Federal Office of Agriculture (FOAG)

\begin{abstract}
Root and foot diseases severely impede grain legume cultivation worldwide. Breeding lines with resistance against individual pathogens exist, but these resistances are often overcome by the interaction of multiple pathogens in field situations. Novel tools allow to decipher plant-microbiome interactions in unprecedented detail and provide insights into resistance mechanisms that consider both simultaneous attacks of various pathogens and the interplay with beneficial microbes. Although it has become clear that plant-associated microbes play a key role in plant health, a systematic picture of how and to what extent plants can shape their own detrimental or beneficial microbiome remains to be drawn. There is increasing evidence for the existence of genetic variation in the regulation of plant-microbe interactions that can be exploited by plant breeders. We propose to consider the entire plant holobiont in resistance breeding strategies in order to unravel hidden parts of complex defence mechanisms. This review summarizes (a) the current knowledge of resistance against soil-borne pathogens in grain legumes, (b) evidence for genetic variation for rhizosphere-related traits, (c) the role of root exudation in microbe-mediated disease resistance and elaborates (d) how these traits can be incorporated in resistance breeding programmes.
\end{abstract}

\section{KEYWORDS}

genetic diversity, holobiont, microbiome, plant breeding, pulses, rhizosphere, root exudates, soilborne diseases

\section{1 | INTRODUCTION}

Grain legumes are important protein sources for human food and animal feed, with an annual world production of 27 megatons (Mt) for common bean (Phaseolus vulgaris L.), $14 \mathrm{Mt}$ for dry pea (Pisum sativum L.), $12 \mathrm{Mt}$ for chickpea (Cicer arientinum L.), $7 \mathrm{Mt}$ for cowpea (Vigna unguiculata (L.) Walp.), $6 \mathrm{Mt}$ for lentil (Lens culinaris Medikus), and $4 \mathrm{Mt}$ for faba bean (Vicia faba L.; FAOSTAT, 2016). Besides their widely acknowledged nutritional quality, they provide important ecosystem services and improve soil fertility (Foyer et al., 2016; Lupwayi \& Kennedy, 2007; Rubiales \& Mikic, 2014). Through the symbiotic association with nitrogen $(\mathrm{N})$-fixing rhizobia, legumes provide $\mathrm{N}$ to the agro-ecosystem, substantially reducing the need for external $\mathrm{N}$ fertilization. Replacing this biologically fixed $\mathrm{N}$ by mineral fertilizer would cost up to an estimate of $\$ 10$ billion per year worldwide (Graham \& Vance, 2003). Leguminous crops are also valuable partners in various intercropping systems throughout the world, providing a means of diversification of cropping systems (Taschen et al., 2017; Wang et al., 2017). Recently, Reckling et al. (2016) showed that replacing mineral fertilizer with legumes in European cropping systems substantially reduces environmental impact in terms of nitrate leaching and nitrous oxide emissions while maintaining economic profitability 
of the system. Despite their ecological and economic importance, legume cultivation remains below expectations due to low and unstable yields, mainly because of biotic and abiotic stresses (Graham \& Vance, 2003; Karkanis et al., 2016; Zander et al., 2016). It has repeatedly been shown that successively growing legumes on the same field leads to the build-up of various root-infecting fungi, oomycetes, and nematodes, resulting in a phenomenon called "soil fatigue," also referred to as "legume yield depression syndrome" or "soil sickness" (Bainard et al., 2017; Emden, Ball, \& Rao, 1988; Fuchs et al., 2014; Huang et al., 2013; Li et al., 2014). Nayyar et al. (2009) showed that 11 years of continuous pea monocropping led to a substantial increase in root rot and a concomitant grain yield reduction of $70 \%$ compared with a pea-wheat rotation. These symptoms were associated with a decrease in overall soil microbial biomass and activity in general and a reduction of arbuscular mycorrhizal fungi (AMF) in particular. Bainard et al. (2017) confirmed these observations assessing different legume-wheat crop rotations and showed that the inclusion of two or more grain legumes into a 4-year crop rotation caused a significant shift in the soil fungal community, a decrease in fungal diversity, and an increase in fungal pathogens. Accordingly, not only a mere accumulation of pathogens is responsible for the yield reduction in continuous legume cultivations, but also actual shifts in the microbial community that can lead to devastating dysbiosis in the rhizosphere. As a consequence of soil fatigue in legume cultivation, rotation breaks of up to 10 years are recommended for certain legume crops (Moussart, Even, \& Tivoli, 2013; Wilbois et al., 2013). This stands in sharp conflict with efforts to increase acreage of legumes to meet the increasing protein demand of a growing world population and to strengthen low input farming systems.

Breeding for resistance has been proposed as the most efficient, economical, and sustainable approach for controlling diseases in legumes (Rubiales et al., 2015). Substantial progress has been made in the development of genetic material resistant to individual pathogens and the elucidation of the underlying genetic basis of resistance traits. However, plant-pathogen interactions are embedded in complex interdependencies among all the microorganisms present in a given space around the plant, that is, the rhizosphere in the case of soil-borne pathogens. Breeding for complex traits such as resistance against soil fatigue is a challenging endeavour, but will eventually lead to more sturdy agro-ecosystems. Thanks to intensive research on soil microorganisms in the rhizosphere, it became evident that the performance of a plant is strongly dependent on the interaction with the associated microbial community (Andreote \& de Pereira e Silva, 2017; Bulgarelli et al., 2015; Hartman, van der Heijden, Roussely-Provent, Walser, \& Schlaeppi, 2017). Plants are in a constant metabolic crosstalk with the associated microbiome. They are a driving force in assembling microbial communities in their vicinity and shape the root-associated microbial community through the release of root exudates that can have stimulating or suppressive action on microbes (Bais, Weir, Perry, Gilroy, \& Vivanco, 2006; Hartmann et al., 2009; Lakshmanan, 2015). Plants and their associate microbiome can be recognized as the holobiont, and it has been postulated that the beneficial interplay of the host plant and its microbiome is responsible for maintaining health, whereas diseases, as outlined above, are correlated with microbial dysbioses (Berg, Köberl, et al., 2017).
The aim of this review is to examine the interplay between plant genotype, rhizosphere microbial communities, and root exudation and its implications for resistance breeding of grain legumes against fungal root diseases (for key messages, see Box 1). A broad overview of the most important fungal pathogens and resistance capacities in legume germplasm collections is followed by the current understanding of plant-pathogen interactions in the rhizosphere. The role of root exudates in direct or microbe-mediated disease resistance is depicted. Eventually, we will discuss how plant genetic diversity for rhizosphere-related traits could be utilized in legume breeding to develop cultivars with increased and stable resistance against soil-borne pathogen complexes.

\section{Box 1. Key messages}

- Grain legume cultivation is severely impeded by rootinfecting pathogens. The control of these fungal and oomycotan pathogens is challenging, as they occur as pathogen complexes in the field. Past and ongoing efforts to develop resistant cultivars in legume breeding have only shown partial success.

- Disease resistance against soil-borne pathogen complexes is not a mere plant, but a system trait involving close interactions of the plant with the rootassociated microbial community.

- Various compounds exuded by plant roots influence the composition and activity of the microbial community.

- New sequencing technologies allow to investigate plant genotype-microbiome interactions. Most importantly, they allow ...

... to identify key players in pathogen complexes and key beneficial microbes that strengthen plant health and defence and

... to elucidate mechanisms involved in microbiomemediated disease resistance.

- Recent insights into the genetic basis of plantmicrobiome interactions provide opportunities for resistance breeding of legumes.

\section{1 | Major root diseases of grain legumes}

The cultivation of grain legumes is severely compromised by root and foot diseases caused by many pathogens. This paper concentrates on important soil-borne fungal and oomycotan diseases. Nematodes are not included, although they are important soil-borne pests in legume cultivation (Rubiales et al., 2015; Sharma, Sikora, Greco, Vito, \& Caubel, 1994). They are involved in a complex interplay with other soil microbes, as illustrated, for example, for chickpea where different nematode species interact with rhizobia and fungal pathogens (Castillo, Navas-Cortés, Landa, Jiménez-Díaz, \& Vovlas, 2008). Plants affected by fungal root and foot rots show various symptoms. These include brown to black lesions, spreading from the upper part of the 
main root into the root system and the stem; discoloration of the root system; and softening and decay of the root and lower stem cortex. The above ground parts of the plant exhibit pronounced wilting, poor growth, and premature collapsing, often leading to complete crop failure.

Among soil-borne fungal pathogens, species of the Ascochyta complex are considered to be a very important biotic constraint in legume cultivation. Ascochyta foot rots are caused by the pathogen species Didymella pinodes (Syn. Peyronella pinodes or Mycosphaerella pinodes) and Peyronella pinodella (Syn. Didymella pinodella or Phoma medicaginis var. pinodella) and represent a threat to legume cultivations worldwide (Aveskamp, de Gruyter, Woudenberg, Verkley, \& Crous, 2010; Baćanović-Šišić, Šišić, Schmidt, \& Finckh, 2017; Barilli, Cobos, \& Rubiales, 2016; Haware, 1981; Tran, You, Khan, \& Barbetti, 2016). These phytopathogenic fungi are responsible for severe leaf and stem spots and root rots on many legume host plants including pea, chickpea, lentil, and faba bean (Muehlbauer \& Chen, 2007). The genus Fusarium comprises several species that can cause severe root rot impeding cultivation of pea and common bean worldwide (Coleman, 2016; Hwang, Chang, Strelkov, Gossen, \& Howard, 2014). For instance, Fusarium solani and Fusarium avenaceum were among the most frequently isolated pathogens in the most important pea production regions of North America (Chittem et al., 2015; Feng et al., 2009; Taheri et al., 2017). Yield losses were reported to reach up to $57 \%$ and $84 \%$ for pea and common bean, respectively (Basu, Brown, Crête, \& Al, 1976; Schneider, Grafton, \& Kelly, 2001). Fusarium root rot is also responsible for high yield losses in white lupine (L. albus) cultivation and seems to play some role in chickpea and lentil root rot (Abdel-Monaim \& Abo-Elyousr, 2012; Azevedo et al., 2017; Nene, Reddy, Haware, \& Ghanekar, 2012; Raza, Christiansen, Jørnsgård, \& Ortiz, 2000). Rhizoctonia solani is one of the main soil-borne pathogenic fungi causing seed rot, damping-off, seedling blight, and root rots on pea, chickpea, bean, lupine, and lentil (Abdel-Monaim \& Abo-Elyousr, 2012; Abdel-Monaim, Abo-Elyousr, \& Morsy, 2011). The $R$. solani species complex is composed of 14 genetically diverse anastomosis groups showing different host ranges and pathogenicities (Kraft \& Pfleger, 2001; Melzer, Yu, Labun, Dickson, \& Boland, 2016). Chickpea production is severely affected by various isolates belonging to several anastomosis groups of this fungus (Dubey, Tripathi, Upadhyay, \& Deka, 2014). Despite infrequent isolations from roots affected by a root rot complex, $R$. solani could be related to stand loss of pea (Mathew et al., 2012). Besides fungi, two important members of the fungus-like class Oomycota, namely, Aphanomyces euteiches and Pythium spp., cause severe economically important diseases of several legume crops. A. euteiches is recognized as one of the most destructive soil-borne pathogens to pea and common bean, especially in France, North America, and Australia (Gaulin, Jacquet, Bottin, \& Dumas, 2007; Hagerty et al., 2015; Watson, Browne, Snudden, \& Mudford, 2013). There are also reports of lentil fields in North America being affected by A. euteiches (Vandemark \& Porter, 2010). The taxon Pythium spp. comprises various globally distributed pathogen species causing preemergence and postemergence damping-off of pea, lentil, chickpea, bean, and lupine (Alcala et al., 2016; Bahramisharif et al., 2014; Ingram \& Cook, 1990; Li et al., 2013; Mathews, Ogola, Botha, Magongwa, \& Gaur, 2016; Nzungize \& Lyumugabe, 2012; Rossman et al., 2017).
In the past, much research has been focused on single pathogen species and their life cycles and infection strategies have been thoroughly summarized (Allen \& Lenné, 1997; Gaulin et al., 2007; Nzungize \& Lyumugabe, 2012). Recent research in legume diseases has increasingly focused on the co-occurrence of various pathogens as complexes (Baćanović-Šišić et al., 2017; Chittem et al., 2015; Taheri et al., 2017). Although many pathogens of legumes have a global distribution, regional structuring of abundance exists. For example, A. euteiches, a major pathogen in pea cultivation of northern France and Sweden, has not been detected in German pea cultivation systems (Gaulin et al., 2007; Heymann, 2008; Pflughöft, 2012). Furthermore, the causal pathogens and their relative significance in root rot complexes can vary by region, as shown for pea-producing areas in North America (Taheri et al., 2017). In this latter study, it was shown that several pathogens are present simultaneously in diseased peas and that their relative prevalence differed from 1 year to the other, with F. solani favoured by drier conditions compared with F. avenaceum and Peyronellaea spp. Various pathogens are also associated with foot and root rot complex of faba beans (Sillero et al., 2010). Species of the genus Fusarium are most abundant, but other pathogenic fungi, including R. solani, Pythium spp., Phoma spp., and A. euteiches, are simultaneously present in the pathogen complex.

Root and foot rots are difficult to control, as their causal agents can survive for many years either as saprophytes on plant residues or in the soil through the formation of resting structures. Furthermore, different pathogens present in the soil complement each other with respect to their ecological niche and infection strategies and even facilitate infection, as further exemplified below. Direct control of these pathogens by chemical fungicides is generally limited and recent regulatory actions concerning pesticide use call for alternative solutions. Some control of soil-borne diseases is usually achieved through sowing of certified seed, avoidance of infested field plots, and the application of long crop rotation breaks (Katan, 2017). So far, it has been difficult to diagnose pathogen occurrences in the soil, but a soil-based bioassay has been developed that can be used to determine the disease potential of agricultural fields (Fuchs et al., 2014).

\section{2 | Resistance breeding against root diseases}

For the long term, resistance breeding has been acknowledged as one of the most promising approaches to achieve sustainable and affordable success against soil-borne diseases (Rubiales et al., 2015; Russell, 1978). Different international grain legume germplasm collections have been characterized for resistance and sources could be identified that show some level of resistance to particular soil-borne pathogens. Infantino et al., (2006) thoroughly reviewed sources of resistance to root diseases in legumes. Hence, only a few examples of resistance screenings will be mentioned below, in order to complement information on resistance screenings and detection of genomic regions associated with disease resistance, and to discuss some commonalities of these studies.

Germplasm with moderate resistance against Fusarium root rot exists for common bean, pea, and lupine (Grünwald et al., 2003; Hagerty et al., 2015; Raza et al., 2000; Silbernagel, 1990). Only intermediate levels of resistance against $D$. pinodes and $P$. pinodella exist in pea 
germplasm despite considerable screening efforts (Carrillo, Rubiales, Pérez-de-Luque, \& Fondevilla, 2012; Fondevilla, Satovic, Rubiales, Moreno, \& Torres, 2007; Khan et al., 2013; Kraft, Dunne, Goulden, \& Armstrong, 1998; Prioul, Deniot, Morin, Frankewitz, \& Baranger, 2004). Moderate resistance to Rhizoctonia root and stem rot was found in pea, chickpea, and lentil germplasm (Chang et al., 2006; McCoy \& Kraft, 1984; Shehata, Davis, \& Anderson, 1981; Talekar, Lohithaswa, \& Viswanatha, 2017; Wang et al., 2006). Moderate to high resistance against Pythium damping-off was found for pea (Ohh, King, \& Kommedahl, 1978), common bean (Li, You, Norton, \& Barbetti, 2016; Nzungize \& Lyumugabe, 2012), and chickpea (Kumar, Kaiser, \& Hannan, 1992). For pea, partial resistance has also been found against $A$. euteiches, (Malvick \& Percich, 1999; Wicker, Moussart, Duparque, \& Rouxel, 2003).

Commercial cultivars of grain legumes generally show low resistance levels. Resistant germplasm is regularly detected among landraces, gene bank accessions, or related species or subspecies. For instance, the Mesoamerican bean landrace Puebla 152 shows enhanced resistance against Fusarium root rot compared with the cultivar Zorro (Nakedde, Ibarra-Perez, Mukankusi, Waines, \& Kelly, 2016). Likewise, in a screen of 304 faba bean accessions and cultivars for resistance against nine different isolates of $R$. solani, gene bank accessions showed higher levels of resistance, and against more R. solani isolates, compared with commercial cultivars (Rashid \& Bernier, 1993). Similarly, in lupine, gene bank accessions examined in F. avenaceum sick soil showed higher resistance than commercial cultivars (Chang et al., 2014). Apparently, gene banks harbour the genetic potential to breed grain legumes for resistance against different forms of root rot. In Egypt, for example, two lupine cultivars resistant to Fusarium root rot were specifically developed from resistant landraces (Raza et al., 2000). However, the use of resistance sources is hampered by the complex inheritance of the resistance and by the complex resistance mechanisms involved, in particular in the presence of various pathogens in the field, as will be shown in the next section.

Resistance to root rots is a quantitative inherited trait. Biparental linkage analysis and genome-wide association studies (GWAS) have been used to map quantitative trait loci (QTL) for resistance against various root pathogens in grain legumes. Resistance to Fusarium and Aphanomyces root rot has been mapped in common bean, with a colocalization of resistance and root morphology-related QTL, indicating that a combination of physiological mechanisms and root architecture traits is responsible for disease resistance (Hagerty et al., 2015 Nakedde et al., 2016; Navarro, Sass, \& Nienhuis, 2008; Schneider et al., 2001). In pea, extensive mapping studies have been conducted for Fusarium and Aphanomyces root rots, and colocalization of rootarchitecture and resistance QTL have been evidenced, too (Coyne et al., 2015; Desgroux et al., 2016; Desgroux et al., 2018, 2018; Feng et al., 2011; Hamon et al., 2011; Li et al., 2012; Pilet-Nayel et al., 2002, 2005). Regarding D. pinodes, the most virulent pathogen of the Ascochyta complex, several QTL studies identified and reconfirmed genomic regions controlling resistance in pea (Carrillo et al., 2014; Fondevilla et al., 2007, 2011). These studies contribute considerably to the progress in identifying genomic regions involved in resistance against root pathogens. However, there is a need to identify the genes underlying the QTL involved in resistance or at least molecular markers more tightly linked to them, which would allow designing marker-assisted selection (MAS) approaches in grain legume breeding. Although there are promising indications to apply MAS in resistancebreeding programmes of legumes, so far, these tools have rarely been adopted by legume breeders (Khan et al., 2013; Rubiales et al., 2015). Next-generation genotyping (e.g., single nucleotide polymorphisms; SNP) will allow to generate high-density genetic maps and to refine mapping of agronomic traits, such as resistance against pathogens. Improved phenotypic scoring of resistance among assessed accessions (e.g., digital image analysis; Desgroux et al., 2018) will further contribute to improving QTL analysis and it seems likely that in the near future, mapping studies will identify more genomic regions, candidate genes, and markers for potential MAS. Hamon et al. (2013) conducted a QTL meta-analysis over four mapping-populations and found seven highly consistent genomic regions associated with resistance of pea against $A$. euteiches. This analysis integrated data of 29 field environments on 2 continents and 12 controlled condition-assays over several years. Similarly, Desgroux et al. (2016) used 13,204 SNP to genotype 175 pea accessions and performed resistance screenings in field and controlled conditions for resistance to A. euteiches. Using GWAS, they found 52 QTL of small-size intervals and validated most previously defined resistance QTL. Moreover, they identified putative candidate genes with various associated functions.

Most importantly, the study by Desgroux et al. (2016) included various field conditions and controlled condition assays with two distinct pathogen strains, making the identified genomic regions a valuable resource for future breeding efforts in pea. Although they detected QTL consistent over the different environments, significant plant genotype $\times$ environment $(G \times E)$ and plant genotype $\times$ pathogen strain interactions were observed. Strong $\mathrm{G} \times \mathrm{E}$ interactions cause low heritability of the assessed traits, such as disease resistance against root rot pathogens, and are a major constrain for the identification of significant genomic regions governing resistance under field conditions (Acquaah, 2012). Besides climate and physical/chemical soil properties, an important driver of $\mathrm{G} \times \mathrm{E}$ involves the entire plant-associated microbial community, including the varying abundance and virulence of different pathogen species and strains. A drawback of a large part of the above-cited studies is that they were performed in controlled conditions on a sterile substrate and artificial inoculation of a pathogen strain. Although this allows to apply well-defined disease score ratings and obtain reproducible susceptibility levels of tested accessions, this does most probably not reflect the situation in the field where plants interact with a wide variety of different microorganisms. Screening crops for resistance under the assumption that a wide range of possible causal agents is present in the field will be a complicated endeavour. Clearly, it will be challenging to design reliable tests for the evaluation of cultivar reactions against pathogen complexes.

\section{I COMPLEX INTERACTIONS BETWEEN GRAIN LEGUMES AND THEIR ROOT- ASSOCIATED MICROBIOTA}

\subsection{The dilemma with pathogen complexes}

Plant roots are involved in a myriad of interactions with different soil microbes, ranging from beneficial alliances with mycorrhizal fungi, 
other fungal root endophytes, and plant growth-promoting rhizobacteria, to detrimental associations with pathogenic bacteria, fungi, and oomycetes (Dudeja, Giri, Saini, Suneja-Madan, \& Kothe, 2012; Müller, Vogel, Bai, \& Vorholt, 2016). In contrast, plant pathology has focused its research mainly on two-way pathogen-host interactions. The identification of resistant plant genotypes and the underlying resistance mechanisms is usually achieved by artificial inoculation of genetically different plant accessions with single pathogen strains on sterile substrate or in fields with confirmed preponderance of a single pathogen species. Today, it is acknowledged that plant diseases are often caused by multilateral interactions among different pathogens and that pathogens need to be considered as parts of microbial complexes (Abdullah et al., 2017; Lamichhane \& Venturi, 2015). Different pathogen species or strains of the same species can infect a plant simultaneously and lead to a different disease expression than infection by a single pathogen. Below, we draw upon several examples of coinoculation of pathogens in legume crops to illustrate how important it is to consider multimicrobial interactions to make progress in understanding root and foot rot phenomena in grain legumes.

More than half a century ago, Kerr (1963) saw that conjoined infection of pea with Fusarium oxysporum and Pythium ultimum leads to a significant increase of disease development compared with single inoculations. Likewise, Pfender and Hagedorn (1982) observed that $P$. ultimum and A. euteiches infect snap bean (Polypodium vulgare) simultaneously, and that disease severity is significantly higher if both pathogens infect the host plant. F. solani frequently acts in complexes with other pathogens such as R. solani, F. oxysporum, A. euteiches, or P. ultimum to infect pea (Mathew et al., 2012; Tu, 1991). Peters and Grau (2002) inoculated two pea cultivars with A. euteiches and a nonpathogenic strain of F. solani separately or together and observed an increase in Aphanomyces root rot symptoms with coinoculation of both microorganisms. Different pathogen species may also inhibit each other. For alfalfa (Medicago truncatula), coinoculation with both $A$. euteiches and $P$. pinodella resulted in significantly reduced amounts of $P$. pinodella DNA compared with the individual inoculation (Hossain, Bergkvist, Berglund, Mårtensson, \& Persson, 2012). Similar results have also been obtained with coinoculation of $A$. euteiches and Phytophthora medicaginis (Vandemark, Ariss, \& Hughes, 2010). In pea, the infection with an endophytic Fusarium equiseti strain reduces disease severity and biomass reduction caused by $F$. avenaceum and $P$. pinodella (Šišić et al., 2017). Similar results were obtained with nonpathogenic F. oxysporum isolates protecting pea against F. solani (Oyarzun, Postma, Luttikholt, \& Hoogland, 1994). Interestingly, other strains of F. oxysporum and Fusarium equiseti can cause disease on a wide range of different legume hosts (Berg, Miller, Dornbusch, \& Samac, 2017; Goswami et al., 2008; Li, Zhang, Sun, Li, \& Ji, 2017). The fact that the same fungal species is found to be pathogenic in some experiments and nonpathogenic in others indicate how disputable the term "(non-) pathogen species" is. This coarse classification neglects that the taxonomic level "species" often includes different strains with distinctive biological features. Moreover, the pathogenicity of microbial species and their more or less detrimental interactions with the plant host has to be conceived within the framework of the whole microbiome
(Berg, Miller, et al., 2017). Specific host resistances against pathogens identified in a certain environment do not necessarily translate to other environments. For instance, pea-breeding lines exhibited different levels of tolerance to $A$. euteiches when evaluated at two different locations in the north-western USA (Weeden, McGee, Grau, Muehlbauer, 2000). Hamon et al. (2011) identified certain resistance QTL (Ae-Ps2.2 and Ae-Ps4.1) only in French, but not in US field experiments. The authors of the latter studies argue that diversity of $A$. euteiches at the different field sites and a possible occurrence of other pathogens, namely, Fusarium ssp. and P. pinodella, explain site-specific resistance rankings and detected QTL. Abdullah et al. (2017) concluded that resistance capacities of pea cultivars against single pathogens, especially when determined under gnotobiotic conditions, have limited transferability to complex field conditions. To overcome such limitations, it is necessary to consider complex plant-microbe interactions and develop screening systems that account for multiple interactions among pathogens, beneficial microbes, and the host plant genotype.

\section{2 | Plant-microbe interactions and disease resistance}

Certain members of the microbial community play a crucial role in the expression of disease resistance of plants. Mechanisms by which beneficial microorganism protect crop plants from diseases include (a) enhancement of overall vigour (e.g., via nutrient mobilization), (b) direct antagonism via parasitism or antibiosis (feeding directly on phytopathogenic microbes or producing antifungal/antibacterial metabolites), (c) niche exclusion (e.g., competition for resources), and (d) induction of systemic and localized resistance (Conrath et al., 2006; Shoresh, Harman, \& Mastouri, 2010; Sindhu, Dua, Verma, \& Khandelwal, 2010; Verma, Adak, \& Prasanna, 2016; Xue, 2003). For instance, Trichoderma belongs to one of the best-studied genera with antagonistic activity against a wide range of root pathogens (Harman, Howell, Viterbo, Chet, \& Lorito, 2004). Trichoderma spp. are well known to proliferate and function in association with plant roots (Hohmann, Jones, Hill, \& Stewart, 2011, 2012). This ability has been identified as one of the most important factors for their potential to control root pathogens. For legumes, Trichoderma spp. were shown to be an effective biocontrol agent against Rhizoctonia seedling mortality and foot rot in pea and common bean (Akhter et al., 2015; Aziz, El-Fouly, El, \& Khalaf, 1997; Nelson, Harman, \& Nash, 1988; Toghueo et al., 2016). AMF are also known to alleviate disease in grain legumes and other crops (Bodker, Kjoller, \& Rosendahl, 1998; Dehariya, Shukla, Sheikh, \& Vyas, 2015; Hilou, Zhang, Franken, \& Hause, 2014; Ren et al., 2015). Other fungi do not necessarily need to colonize plant roots to confer protection against pathogens, as shown for the biocontrol fungus Clonostachys rosea. This mycoparasite was shown to effectively protect pea seedlings against different pathogenic microbes (Xue, 2003). Along with fungi, bacteria endophytically associate with plant roots and confer protection against pathogens (Dudeja et al., 2012; Rybakova et al., 2016). In the first place, rhizobia strains protect legumes against root diseases, such as Pythium damping-off in pea and lentil (Bardin, Huang, Pinto, Amundsen, \& Erickson, 2004; Huang \& Erickson, 2007). Antagonistic activity of 
rhizobia against pathogens is attributed to production of antibiotics and antifungal compounds or to the induction of systemic resistance and enhanced expression of plant defence-related genes (Das, Prasanna, \& Saxena, 2017; Desalegn, Turetschek, Kaul, \& Wienkoop, 2016). Besides rhizobia, various naturally occurring bacteria associate with plant roots and are effective biocontrol agents against bacterial and fungal diseases. Several plant growth-promoting rhizobacteria were shown to have such biocontrol properties in pea (Singh, Prithiviraj, Singh, \& Sarma, 2000), chickpea (Akhtar \& Siddiqui, 2009; Egamberdieva, Wirth, Shurigin, Hashem, \& Abd-Allah, 2017; Misk \& Franco, 2011), pigeon pea (Dutta, Morang, Nishanth Kumar, \& Dileep Kumar, 2014), and common bean (Hsieh, Huang, \& Erickson, 2005; Lopes, de Oliveira Costa, Vanetti, de Araújo, \& de Queiroz, 2015).

Different beneficial microorganisms interact and this microbial crosstalk has important consequences for plant health (Cameron, Neal, van Wees, \& Ton, 2013; Shtark, Borisov, Zhukov, \& Tikhonovich, 2012). Palmieri, Vitullo, de Curtis, and Lima (2017) showed that a microbial consortium of four beneficial rhizobacteria controls $F$. solani and $F$. oxysporum of chickpea more efficiently than each bacterial isolate on its own. The control of red crown rot in soybean (Glycine max) is more efficient when coinoculating AMF and rhizobia compared with single inoculations with either symbiont (Gao et al., 2012). The coapplication of various pathogen and antagonistic microbial strains is a promising approach to identify microbial key players that are active in more complex systems.

Controlled experiments and coinoculations depict the tripartite interaction between host plant, pathogens, and beneficial microbes in a useful, though simplistic, way. The situation in the field is more complex and disease severity or suppression of soil-borne diseases are the result of a complex interplay within the microbial community present in a given soil (Lareen, Burton, \& Schäfer, 2016). New sequencing technologies enable rapid and cost-effective whole microbiome surveys of crop plants. Microbiome comparisons between cultivars with contrasting susceptibility to diseases and between different agricultural management practises are of particular interest in this regard. For instance, amplicon sequencing of rootassociated fungal communities of pea with different disease expression show clear shifts in community composition between healthy and diseased pea (Xu, Ravnskov, Larsen, \& Nicolaisen, 2012; Yu, Nicolaisen, Larsen, \& Ravnskov, 2012). Notably, the health status of pea positively correlates with the abundance of AMF. Similar observations were made for long-term peanut monocultures, where plant pathogenic fungi accumulated in the soil at the expense of beneficial fungi (Li et al., 2014). Zhang et al. (2017) took microbiome analysis a step further in their study on the sick soil phenomenon in monocropped tobacco fields. Combining amplicon sequencing with a functional gene analysis, the authors showed a shift in the microbial community composition to be accompanied by changes in the metabolic potential of genes involved in stress, virulence, and plant cell wall degradation in the sick soil. Poor soil properties lead to a decrease of beneficial microorganisms and a build-up of soil-borne wilt-causing bacteria. Research in this direction complements our understanding about the involvement of individual microbes in crop health. This will allow to progressively disentangle functional plantmicrobe and microbe-microbe interactions.

\section{3 | Plant genotype drives the microbial rhizosphere composition}

It is well known that different plant species have distinct rootassociated microbiomes (Doornbos, van Loon, \& Bakker, 2011; Garbeva, van Elsas, \& van Veen, 2007; Toju et al., 2013). The selective effects of crop species on microbial communities can be very specific. For instance, it was shown that chickpea, lentil, and pea have different root-associated fungal communities in general, but that AMF communities do not differ between the three crops (Borrell et al., 2017). Besides interspecies variation, microbial composition in the rhizosphere also differs between genotypes of the same species and Coleman-Derr and Tringe (2014) highlighted the role of microbial communities to confer stress tolerance to their host plants. In 1904, Lorenz Hiltner postulated the pioneering idea that the resistance of pea against soil fatigue depends on the composition of the microbial community in the rhizosphere (Hartmann, Rothballer, \& Schmid, 2008). Only with the advent of next-generation sequencing technologies has it been possible to elucidate the composition of soil microbial community in recent years. Several studies investigated the effect of the host genotype on the microbial community composition. For instance, Zancarini, Mougel, Terrat, Salon, and Munier-Jolain (2013) reported significant differences in the genetic structure and diversity of the entire bacterial rhizosphere community between seven genetically diverse Medicago truncatula lines at an early growth stage. The rice genotype explained $30 \%$ of the variation in the microbial rhizosphere composition (Edwards et al., 2015). In an extensive survey of the potato-associated microbiome, Weinert et al. (2011) showed that $9 \%$ of all detected operational taxonomic units revealed a cultivar-dependent abundance. Different maize cultivars were shown to differentially stimulate rhizobacteria and AMF populations (Picard, Baruffa, \& Bosco, 2008), and significant genotypic effects among 10 maize inbred lines accounted for $26 \%$ of the variation in the bacterial rhizosphere composition (Emmett, Youngblut, Buckley, \& Drinkwater, 2017). Peiffer et al. (2013) showed that plant genotype explains a small but significant part of the total observed bacterial diversity in the rhizosphere among 27 modern maize inbred lines evaluated in different field environments. Ellouze et al. (2013) detected genotypic effects of chickpea on soil microbial diversity (using cultural methods) and their impact on the subsequent durum wheat (Triticum durum) crop. However, this effect was diminished under severe drought. A genotypic effect on the root and rhizosphere microbiome was also detected in barley (Hordeum vulgare) (Bulgarelli et al., 2015).

The plant genotype also determines the interaction with individual members of the microbial community in the rhizosphere and evidence for host genotype-dependent interaction exists, for example, for rhizobia (Roskothen, 1989; Yang et al., 2017), AMF (An et al., 2009; Hetrick, Wilson, \& Todd, 1996), and rhizobacteria (Smith \& Goodman, 1999). To date, only few studies have assessed the role of plant genotypic variation in microbe-mediated disease resistance. Mark and Cassells (1996) demonstrated a genotype-dependent interaction between the AMF Glomus fistulosum and Phytophthora fragariae, the causal agent of red stele disease in wild strawberry (Fragaria vesca). Steinkellner et al. (2012) revealed a cultivardependent bioprotection effect of the AMF Glomus mosseae when 
different tomato cultivars were infected with F. oxysporum f. sp. lycopersici. Cultivar-specific root-associated bacterial communities have been found in wheat and maize that differ in their ability to attract naturally occurring DAPG-producing Pseudomonas spp. and the amount of antibiotics produced by the biocontrol strains differed between the cultivars' rhizospheres (Gu \& Mazzola, 2003; Meyer et al., 2010; Wen, Wang, Ti, Wu, \& Chen, 2017). Different cotton cultivars showed significant varietal responses to cyanobacteria and a Trichoderma sp. applied as a biocontrol formulation against a root rot complex in the field (Babu et al., 2015). In lentil, significant plant genotype effects were shown for the interaction with Trichoderma spp. in the presence of the pathogen A. euteiches (Prashar \& Vandenberg, 2017). Although the Trichoderma spp. did not hinder the pathogen from infecting the host, they significantly promoted plant growth under pathogen stressed conditions.

The crosstalk between the plant and the microbial rhizosphere community as a whole is still barely understood. Knowledge of the function and the underlying genetics is still restricted to particular well-studied plant-microbe models, such as the mapping of symbiotic loci related to rhizobial and mycorrhizal symbiosis in model species (Sandal et al., 2006). However, the few cited examples of the relationship between plant genotype, the rhizosphere microbiota, and plant health clearly highlight the vital role of plant-associated microbes in disease resistance. The microbiome composition and specific interactions with fungal and bacterial strains have direct implications for phytopathology and biocontrol of plant pathogens. Plant breeding is the means by which genotypic differences for rhizosphere-related traits can be exploited and a favourable rhizosphere microbiota with specific microbial antagonists will lead to improved indirect plant defences against root pathogens.

\section{3 | THE ROLE OF ROOT EXUDATES IN DISEASE RESISTANCE OF LEGUMES}

Plants release considerable amounts of photosynthetically fixed carbon from their roots in form of carbohydrates, amino acids, organic acids, growth factors, lipids, and enzymes, and, thus, provide considerable portions of carbohydrates and $\mathrm{N}$ to the soil microbiota (Curl \& Truelove, 1986). Various organic acids are predominant in root exudates of axenically grown crop plants and the composition of organic acids is markedly changed in the presence of pathogenic fungi (Kamilova et al., 2006; Kamilova, Kravchenko, Shaposhnikov, Makarova, \& Lugtenberg, 2006). Certain organic acids, for example, butanoic acid, ferulic acid, 3-indolepropanoic acid, and rosmarinic acid, were shown to be involved in defence responses of the plant (Bais, Walker, Schweizer, \& Vivanco, 2002; Walker, Bais, Halligan, Stermitz, \& Vivanco, 2003). Owing to the hallmark feature of legumes to form an intimate mutualistic symbiosis with rhizobia, most attention has been paid to root exudates (e.g., flavonoids) involved in the establishment of this symbiotic association (Garg, 2007; Sugiyama \& Yazaki, 2012). However, root exudates have manifold direct and indirect effects on the root-associated microbiota with relevance to pathogen regulation and disease susceptibility (Figure 1).

\section{1 | Root exudates stimulate or suppress soil-borne pathogens}

Root exudates contain compounds that directly stimulate or suppress the growth of soil-borne plant pathogens. They provide an appropriate carbon source for many soil microbes (Bais et al., 2006). For instance, germination of oospores of two strains of $A$. euteiches isolated from pea roots is significantly stimulated by pea root exudates compared with exudates of other crop plants (Shang, Grau, \& Peters, 2000). Different sugars and also amino acids present in root exudates stimulate chemotaxis, encystement, and cyst germination of the soy pathogen Phytophtora sojae (Suo et al., 2016). It was shown that artificially amending soils with root exudates of legume plants leads to an increase of fungal biomass in the rhizosphere (Broeckling, Broz, Bergelson, Manter, \& Vivanco, 2008; Li et al., 2014). Besides many compounds commonly exuded by plants, there are several ones that are specifically released from the roots of legumes such as the strigolactone-like metabolites peagol and peagoldione with germinative activity on broomrape (Orobanche crenata) seeds (Evidente et al., 2009). Root exudates of pea cultivars were shown to stimulate the germination of microconidia and chlamydospores of pathogenic F. oxysporum, macroconidia of $F$. solani, and oospores of $A$. euteiches (Whalley \& Taylor, 1973). Intriguingly, macroconidia germination of F. solani is also highly stimulated by other flavonoids known to induce nod genes in Rhizobium leguminosarum bv. viciae, the rhizobial symbiont of pea (Ruan, Kotraiah, \& Straney, 1995). This suggests that F. solani is capitalizing on molecules that are released by pea roots for the purpose of the molecular crosstalk with their bacterial root symbionts. The stimulatory effect on macroconidia was reduced for F. solani strains that are associated with beans or absent in the case of strains associated with nonlegume plants, pointing at the specificity of the pathogen-host interaction.

Root exudates also comprise a large number of defence-related compounds with manifold effects on various rhizosphere-colonizing microbes, as reviewed by Baetz and Martinoia (2014). For instance, pisatin was the first phytoalexin identified and, since then, its interaction with fungal pathogens has served as a prime example to understand plant pathogenicity and nonhost resistance (Cruickshank \& Perrin, 1960; Hadwiger, 2008, 2015). Pisatin is produced by peas and acts as an important defence molecule against fungal pathogens (Preisig et al., 1990). Detoxification of pisatin by demethylation and subsequent metabolizing allows pathogens to evade plant defence and is associated with pathogenicity in pea, chickpea, and alfalfa (Enkerli, Bhatt, \& Covert, 1998; Hirschi \& Van Etten, 1996; Milani et al., 2012; Soby, Caldera, Bates, \& VanEtten, 1996). Other plant defensins are known, but explicit experimental reports on their occurrence and mode of action in root exudation of legume species is scarce (Hanks et al., 2005; Thomma, Cammue, \& Thevissen, 2002). Certainly, more research is needed to address the importance of defensins in root exudates of legumes and their role in plant defence against soilborne pathogens and to elucidate the genetic basis of defensins exudation and variability. Other antimicrobial compounds found in root exudates include chitinases, glucanases, and lipid transfer proteins that showed inhibitory effects on conidia germination and hyphal growth of F. oxysporum in vitro (Nóbrega et al., 2005). In this latter experiment, 


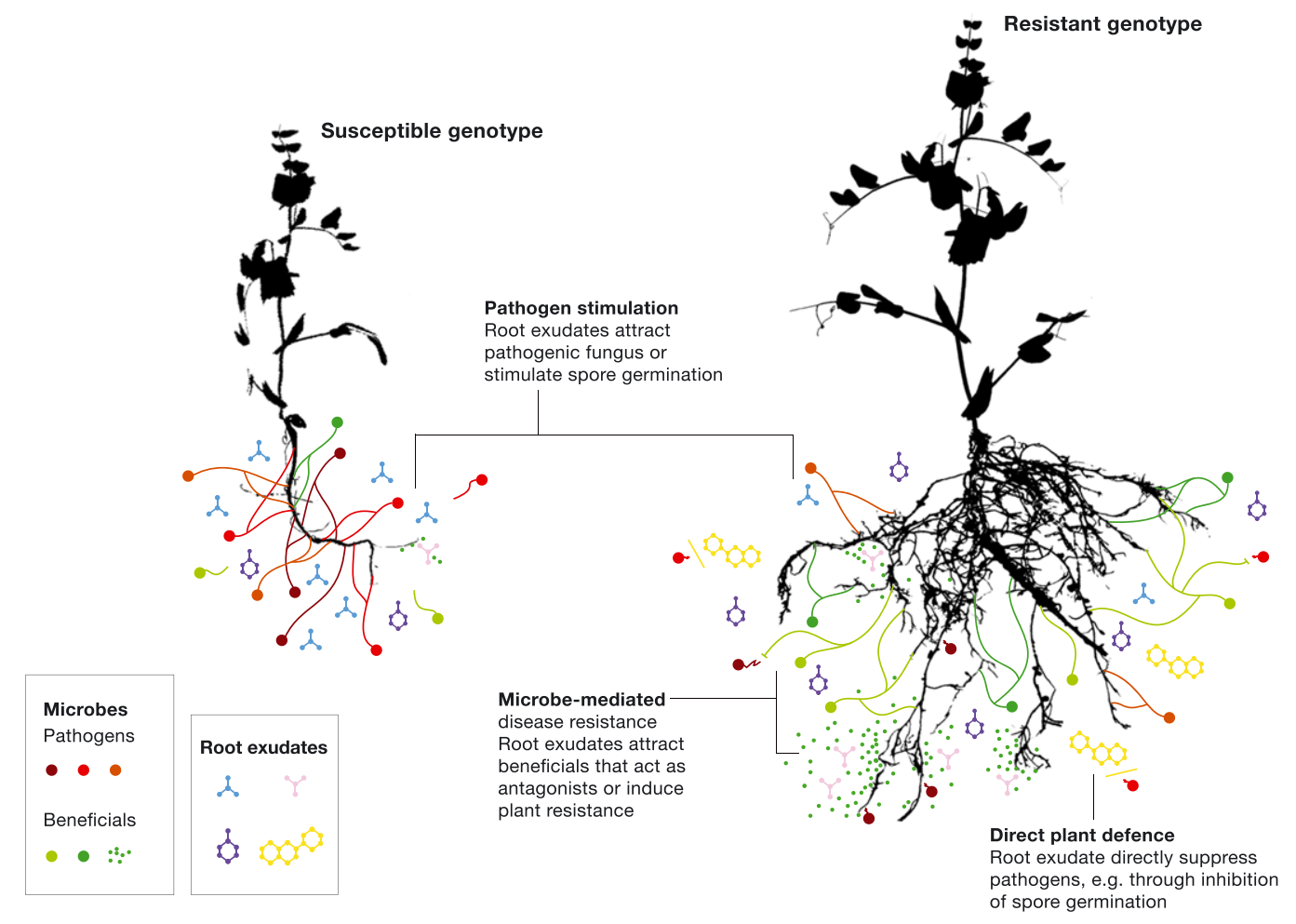

FIGURE 1 Schematic representation of plant genotype-dependent interactions in the rhizosphere. Left: Plant genotype susceptible to a complex of soil-borne pathogens. Right: Resistant plant genotype. Four hypothetical root exuded compounds (mock molecules), three pathogenic microbial species (reddish colours), and three beneficial species (greenish colours) are represented. Note: All microbial species are present in the rhizosphere of both plant genotypes but their relative abundance is different in the two cases. Mainly fungal pathogens are attracted by the susceptible genotype, and the plant is heavily infected, consequently, plant growth is stunted. The resistant genotype exudes either compounds that suppress pathogens directly (yellow) or compounds that attract beneficial microbes that in turn mediate defence against pathogens, for example, through direct antagonism, niche exclusions, or localized or induced systemic resistance

as in many other studies, root exudates were recovered from plants growing in an axenic, pathogen-free hydroponic system, indicating that legumes constitutively exude defence-related compounds into the rhizosphere. Roots may exude important antifungal compounds; however, the susceptibility of plants to fungal pathogens can also depend on entire exudation profiles. For instance, the anthocyanin delphinidin present in seed coats of peas is exuded during germination and has a fungistatic activity against conidial germination of $F$. solani, but this activity is nulled by a sufficient exudation of carbohydrates at the same time (Kraft, 1977). Li et al. (2013) assessed the effect of root exudates of peanut cultivars on different pathogenic fungi and generally observed a stimulation of fungal growth at intermediate concentrations of exudates. However, the stimulation decreased with higher concentrations of exudates, suggesting that the root exudates contained antimicrobial substances along sugars and amino acids. To assess the effect of root exudation on microbiome-related processes and on plant health, it is therefore important to not only identify key root exudate compounds, but also determine exudate composition on a quantitative level.

\subsection{The interplay between root exudates and the microbial community}

Beside direct antimicrobial effects, root exudates also influence plant health indirectly by attracting beneficial microorganisms. Rudrappa,
Czymmek, Paré, and Bais (2008) showed that the secretion of malic acid in Arabidopsis thaliana was induced by pathogenic Pseudomonas syringae that, in turn, led to the recruitment of an antagonistic strain of Bacillus subtilis. Plant growth-promoting rhizobacteria and Trichoderma spp. are readily attracted by organic acids released from roots (Zhang et al., 2014; Zhang, Meng, Yang, Ran, \& Shen, 2014).

The regulation and the composition of root exudates is highly dynamic and changes with the physiological state of the plant (Yuan et al., 2015). Root exudation is also effected by the soil microbial community. For instance, defensin genes are generally upregulated in legumes upon pathogen attack, as shown for the interaction between pea and F. solani (Chiang \& Hadwiger, 1991). Interestingly, the same genes are induced in Medicago truncatula in response to the infection by an AMF, pointing at a possible mechanism of mycorrhiza-mediated disease resistance (Hanks et al., 2005). Besides direct induction of plant defence-related metabolic responses, beneficial microorganisms can also prime the plant, a state of increased alertness (Conrath et al., 2006; Pieterse et al., 2014). Seeds of parasite weeds (e.g., broomrape; Orobanche sp.) conceive root exudates of their host plants as a signal to germinate and subsequently infect the host. Mabrouk et al. (2007) assessed the interaction of rhizobia (Rhizobium leguminosarum), pea root exudates, and broomrape and found that the germination rate of broomrape seeds significantly decreases in the presence of root exudates collected from rhizobia inoculated 
peas. They identified marked changes in root exudate composition following inoculation with rhizobia, notably with significantly higher exudation of various phenolic compounds and flavonoids. Root exudation patterns also change upon contact and colonization by mycorrhizal fungi, with much of the change related to the regulation of the symbiosis itself (Jones, Hodge, \& Kuzyakov, 2004). Strigolactones are involved in the establishment of the mycorrhizal symbiosis. These phytohormones stimulate the spore germination and hyphal branching of AMF, but also trigger seed germination of parasitic plants (Foo \& Reid, 2012; Gomez-Roldan et al., 2008). The chemistry and mode of action of various individual root exudates involved in plant defence are known today. As illustrated, certain compounds have very specific effects on individual microorganisms, whereas others attract or suppress both beneficial and detrimental microorganisms. In turn, the microbial rhizosphere community greatly influenced root exudation of the plant. Consequently, the overall effect of the interplay between root exudates and root-associated microbes is the result of very complex reciprocal processes.

\subsection{Genotypic differences in root exudation}

Several studies on different legume species revealed genotypic differences in root exudate composition and their effect on rhizosphere processes. For instance, chickpea cultivars with different levels of susceptibility to Fusarium wilt vary in their production of chitinase, protease, and glucanase in germinating seeds and in roots leading to distinct effects on F. oxysporum spore germination and hyphal growth (Haware \& Nene, 1984; Stevenson, Padgham, \& Haware, 1995). The expression of these antifungal compounds was shown to be induced in the resistant cultivars upon pathogen attack (Giri et al., 1998). For pea, root exudates of eight different genotypes showed variable effects on quiescence levels in entomopathogenic nematodes (Hiltpold, Jaffuel, \& Turlings, 2015). It was further shown that varying root exudate concentrations had contrasting effects on activity and infectiousness of beneficial as well as parasitic nematodes. For pathogenic fungi, similar contrasting effects of certain root exudate compound levels have been observed. For instance, root exudates of two peanut cultivars significantly differed in their stimulating effect on spore germination, hyphal growth, and sporulation of the fungal pathogens F. oxysporum and F. solani (Li, Huang, et al., 2013). Pavan et al. (2016) reported on a pea landrace highly resistant to a parasitic weed (Orobanche crenata), and that the resistance mechanism is likely due to the reduced secretion of strigolactones. Similar results were obtained with radiation-mutagenized chickpea, where a decrease in stimulatory activity of root exudates towards broomrape seed germination was responsible for strong resistance of some mutants (Brahmi et al., 2016). Genotypic differences for root exudation patterns also exist for other rhizosphere-related processes in legumes (Kato \& Arima, 2006; Rose, Damon, \& Rengel, 2010; Subbarao, Ae, \& Otani, 1997; Wouterlood, Cawthray, Turner, Lambers, \& Veneklaas, 2004). A noteworthy comparable phenomenon to soil fatigue in legumes is the so called "apple replant disease," which is responsible for severe yield reduction in apple production. Recently, Leisso, Rudell, and Mazzola (2017) evidenced differences in root exudation composition among four apple rootstock genotypes that show different levels of resistance to apple replant disease. The authors of this study deployed an elaborate experimental setup to control for rootstock- and root-associated bacterial origin of exudates and for developmental stage of the plant. Although it was not possible to draw a clear partitioning between disease resistant and susceptible genotypes based on patterns of root exudates, particular molecular compounds were significantly more present in individual genotypes. For example, levels of benzoic acid were significantly more produced by a resistant than a susceptible genotype. Benzoic acid is a preferred substrate of the bacterium Burkholderia capacia that was previously shown to be abundant in the rhizosphere of replant disease resistant rootstocks and to act as a biological control against soil-borne pathogens (Pumphrey \& Madsen, 2008).

Genotypic variation in microbial rhizosphere composition can be attributed to a differential exudation of compounds (Aira, GómezBrandón, Lazcano, Bååth, \& Domínguez, 2010; Micallef, Shiaris, \& Colón-Carmona, 2009; Peiffer et al., 2013). For instance, differences in root exudation between one wild type and two mutants of Arabidopsis thaliana are significantly correlated with differences in the bacterial and archaeal community composition in the rhizosphere (Carvalhais et al., 2015). Variation in two plant genes (su1 or sh2) responsible for plant carbon allocation strategy in maize greatly modified the structure and activity of the microbial community in the maize rhizosphere (Aira et al., 2010). These findings demonstrate a genetic basis of the plant to stimulate or inhibit individual microbial strains or entire consortia through regulatory actions such as root exudation. The presented interplay between roots and their associated microbiome through exudates is a key determinant for plant health

\section{4 | INTEGRATING THE MICROBIOME TO IMPROVE RESISTANCE AGAINST BIOTIC STRESSES IN LEGUME BREEDING}

As described in the previous sections, pathogenic and beneficial microorganisms in the rhizosphere interact with each other and the plant host. Despite the complexity of microbe-microbe and plantmicrobe interactions, a solid scientific basis for directed manipulations of these interactions in agro-ecosystems is emerging. Actions targeting plant-microbe interactions will most likely improve plant health and productivity, and thus, lead to more sustainable agriculture (Turner et al., 2013). Plant-microbe interactions can be harnessed either through the direct manipulation in form of an external supply of specific microbes or through plant breeding. We will briefly summarize some recent publications of successful applications of bio-inoculants, before discussing plant breeding for microbiome-mediated disease resistance in the last sections.

\subsection{Increased crop productivity with microbial amendments}

Bio-inoculations are a relatively simple but effective means to increase crop productivity through the amendment of certain 
microorganisms. Seed coating of grain legumes has been especially successful for $\mathrm{N}$-fixing bacteria and mycorrhizal fungi (O'Callaghan, 2016; Oliveira et al., 2017; Patil \& Alagawadi, 2010). A yield increase of $52 \%$ was obtained through coinoculation of chickpea with an $\mathrm{N}$-fixing (Mesorhizobium ciceri) and a P-solubilizing (Pseudomonas jessenii) bacteria (Valverde et al., 2006). Similarly, for mung bean (Vigna radiata), 23\% yield increase was reported after coinoculation with two AMF species (Tarafdar \& Rao, 1997). Yield increases of $20 \%$ and $39 \%$ were obtained with lentil after single or coinoculation with three complementary bacterial strains, respectively (Chandra \& Kumar, 2008). Shcherbakova et al. (2017) identified improved $\mathrm{N}$-fixation, a change in the exudation activity, and the rhizosphere microbiome of chickpea after a combined inoculation with Mesorhizobium sp., Bacillus subtilis, and physiologically active molybdenum. Significantly, these studies moved beyond applications of individual bio-inoculants and showed improved performances with coapplication compared with the individual inoculation of microbes.

Major constraints for a successful establishment of the introduced microbes in the rhizosphere are limited viability and storage time, unfavourable abiotic soil properties or environmental conditions, insufficient competition, or incompatibility of the inoculant with the indigenous microbial community (Abujabhah, Bound, Doyle, \& Bowman, 2016; Chaparro, Badri, \& Vivanco, 2014; Fließbach, Winkler, Lutz, Oberholzer, \& Mäder, 2009; Hu et al., 2017; Mnasri et al., 2017). In the future, it will be possible to introduce more complex microbial associations as synthetic community inoculants (Niu, Paulson, Zheng, \& Kolter, 2017). Cole et al. (2017) proposed a starting point for a targeted improvement of the competitiveness of introduced microbes by identifying 115 genes relevant for the successful colonization of Pseudomonas simiae of plant roots. Such approaches seem very promising and develop into fast-emerging business advances focussing on microbial seed coating (Waltz, 2017).

\section{2 | Engineering the microbial community through plant breeding}

The potential of breeding for microbe-mediated disease resistance in legume crops is based on the hypothesis that plant functions, including resistance to biotic and tolerance to abiotic stresses, are the result of the plant's metagenome that includes the associated internal and external microbes (Berendsen, Pieterse, \& Bakker, 2012; Berg, Miller, 2017; Coleman-Derr \& Tringe, 2014; de Boer, 2017; Mendes, Garbeva, \& Raaijmakers, 2013; Pieterse, de Jonge, \& Berendsen, 2016). This line of thought is additionally fuelled by the new advent in human health research related to the gut microbiome (Gilbert et al., 2016). Vandenkoornhuyse, Quaiser, Duhamel, Le Van, and Dufresne (2015) stressed the holobiont concept as a unit of selection and adaptation, considering the holobiont as one entity or megaorganism including functions and interactions of the plant and all associated internal and external microorganisms (i.e., the plant microbiome). The genetic information of this holobiont is defined as the hologenome. However, Douglas and Werren (2016) argue that selection might not necessarily happen always at the holobiont level, but that both mutualistic and antagonistic evolution (including fitness conflicts) can occur among constituent members of the host-microbiome communities.

\subsection{Selecting against beneficial microbes?}

It has been postulated that plant domestication and breeding, under optimal supply of input factors such as fertilizers, has unintendedly led to selection against a genetically diverse plant-associated microbial community (Bennett, Daniell, \& White, 2013; Bulgarelli et al., 2015; Hohmann \& Messmer, 2017; Morgan, Bending, \& White, 2005; Pérez-Jaramillo, Mendes, \& Raaijmakers, 2016; Wang et al., 2017; Wen et al., 2017). However, although Bulgarelli et al. (2015) could show small but significant differences in root-associated bacterial communities between a wild barley genotype, a barley landrace and the elite cultivar Morex, a general reduction in diversity was not found. Similar results were obtained when comparing ancient and modern maize (Johnston-Monje, Mousa, Lazarovits, \& Raizada, 2014). In contrast, wild beet plants (Beta vulgaris) harboured distinct operational taxonomic units and a more diverse bacterial community than domesticated sugar beet plants (Zachow, Müller, Tilcher, \& Berg, 2014). A more recent study further elaborated on the link between common bean domestication, specific root morphological traits, and rhizobacterial communities and found a higher abundance of Bacteroidetes and less Actinobacteria and Proteobaceria in wild beans compared with modern bean cultivars (Pérez-Jaramillo et al., 2017). A common drawback of most of these studies is the limited number $(<10)$ of genotypes analysed. However, comparing 33 wild populations, landraces and modern cultivars of sunflower (Helianthus annus), a significant shift in the fungal rhizosphere community was observed, but there was no change in bacterial rhizosphere and root community (Leff, Lynch, Kane, \& Fierer, 2017). At the current taxonomic resolution, there seems to be a shift rather than presence-absence of operational taxonomic units along the footprint of domestication. Nevertheless, in situ conservation of crop wild relatives in their centre of origin offer a great potential to rediscover microbial associations that have coevolved with the crop and to support modern breeding programmes aiming at enhanced plant immunity (Hale, Broders, \& Iriarte, 2014).

\subsection{Breed where the microbes are}

Future breeding strategies to promote plant health should focus not only on multiple aspects of a plant in its given environment, including phenotypic, genotypic, and metabolomic data, but also on plant microbial communities and the potential of the plant genotypes to steer their microbial communities (Box 2; Bakker, Manter, Sheflin, Weir, \& Vivanco, 2012; Hartmann et al., 2009; Hohmann \& Messmer, 2017; Lakshmanan, 2015; Pérez-Jaramillo et al., 2016; Smith \& Goodman, 1999; Wissuwa, Mazzola, \& Picard, 2009). Although much more research is needed to close major knowledge gaps and link microbial diversity with function and ecosystem services (Finkel, Castrillo, Herrera Paredes, Salas González, \& Dangl, 2017; Hartman et al., 2017; Oyserman, Medema, \& Raaijmakers, 2018), there are already certain strategies and tools breeders can consider to integrate microbiome functions in breeding programmes. 


\section{Box 2. Microbiome-supported resistance breeding}

- The plant genotype significantly effects the composition of the rhizosphere microbiome.

- Selection of plant genotypes needs to be conducted in environments that reflect the pathogen situation in the field and that are favourable for plant-microbe interactions (i.e., in the absence of pesticides and excessive fertilizers).

- Individual pathogenic or beneficial key players (via realtime quantitative PCR) or whole microbiome profiles (via next-generation sequencing) can be determined to support the selection process in target environments.

- Plant breeders can screen for specific root exudate compounds that are involved in microbiome-mediated disease resistance.

- The heritability of plant resistance traits can be increased through the inclusion of plant genotype $x$ environment $\times$ microbiome interactions.

- The identification of genomic regions associated with microbiome-mediated disease suppression allows to design marker-assisted selection approaches.

- Microbiome-wide association studies can be used to predict plant health-associated capacities of microbial communities. Metagenomic characterization of soil microbiomes allow plant breeders to make wellinformed choices of field sites for selection and variety testing.

Plant selection should occur in its target environment in living soil, allowing to account for plant-microbe and microbe-microbe interactions, as whole microbial communities rather than a few pathogen species might be different in that soil. Gaue (1998) stated that breeding of red clover (Trifolium pratense) against soil-borne fungal diseases is only successful under field conditions. He argued that plant selection needs to be performed in fields where a naturally occurring complex of root rot pathogens is present. The soil fungal community of lotus (Nelumbo nucifera) in healthy and Fusarium wilt-infected fields showed significant differences, indicating reduction of beneficial microorganism and accumulation of fungal pathogens under continuous lotus cultivation (Cui, Wang, Zeng, \& Sun, 2016). These results are in line with the above cited observations on microbial dysbiosis in pea (Xu et al., 2012; Yu et al., 2012), peanut (Li et al., 2014), and tobacco (Zhang et al., 2017). Such an approach will allow to select plant genotypes that associate with a disease-suppressive or "healthy" microbiome that can restrict the virulence of predominant pathogens. Plant breeding typically aims to develop cultivars with best performance over a range of different environments. This makes sense for the breeder from an economic point of view, but does not lead to varieties that are best adapted to local conditions, including efficient interactions with the local microbial community. For instance, Chang et al. (2014) evaluated lupine accessions and cultivars for resistance against $F$. avenaceum in field trials in Canada. Two cultivars, included in the screen, successfully developed for F. avenaceum resistance in Denmark and Germany were not resistant in the Canadian field trial. The authors reasoned that this observation might reflect differences in pathogen strains between Europe and Canada or differences in the environmental factors, including the resident microbial community (see also section "Resistance breeding against root diseases"). Such results show that, in the case of breeding against root rot complexes, only selection under target environment conditions will produce improved cultivars.

Multilocation, multiyear testing is also crucial for the detection of plant genes or genetic loci with influence on the microbiome composition, because experiments under controlled conditions alone, by reducing environmental variability, might overestimate the importance of certain genes (Anderson, Wagner, Rushworth, Prasad, \& Mitchell-Olds, 2013; Wagner et al., 2016). Using naturally infested agricultural soils that harbour multiple pathogens will allow to identify resistances to several interacting pathogens and, thus, better reflect the situation in the field. Experimental fields should be characterized not only for soil type, soil structure, nutrient content, and $\mathrm{pH}$, but also for the microbial bulk soil and rhizosphere community. Chang, Haudenshield, Bowen, and Hartman (2017) were able to identify groups of microbes associated with productivity of soybean based on a metagenome-wide association study assessing bulk soil from different field sites. Subsequently, they used a machine-learning algorithm to successfully predict soybean productivity based on microbiome data. Characterization of the resident field microbiome through metagenomic approaches could allow plant breeders to make well-informed choices of field sites for selection and variety testing.

Besides field screenings, meaningful high-throughput selection can be achieved by standardized growth-chamber experiments that use agricultural field soils instead of sterile substrate. It was shown that disease assessments under controlled conditions can strongly correlate with field ratings (Hamon et al., 2011; Wang et al., 2006), indicating that these screening systems can serve as a valuable tool to identify possible sources of resistance in legumes. In contrast, selection steps conducted in sterile conditions ignore important plant-microbe interactions and might even lead to an overestimation of genotypic effects due to vertically transmitted microbes via seeds (Coleman-Derr \& Tringe, 2014; Johnston-Monje et al., 2014; Johnston-Monje, Lundberg, Lazarovits, Reis, \& Raizada, 2016)

Another approach is to identify and quantify key players from target environments and use a synthetic community (including key pathogen species within a simplified microbial community) as inoculant under controlled conditions (Gopal, Gupta, \& Thomas, 2013; Oyserman et al., 2018). Niu et al. (2017) used a simplified representative bacterial community to study the community assembly dynamics on axenic maize seedlings under presence of root pathogens. Bazghaleh, Hamel, Gan, Tar'an, and Knight (2015) were able to identify significant differences in root fungal community compositions between 13 chickpea cultivars and verified positive and negative effects of certain isolated strains on plant performance in a greenhouse. 


\subsection{The plant-microbiome as a plant trait}

Functional plant-microbiome interactions should be incorporated into breeding processes as a heritable trait. In order to disentangle direct and microbe-mediated resistance and prove the concept of holobiont selection, multifactorial trials are needed to test the genotypes in sterile and nonsterile soils with different level of pathogen pressure. In one of the first studies, Panke-Buisse, Poole, Goodrich, Ley, and Kao-Kniffin (2014) showed that Arabidopsis-associated root microbiomes that were selected for the plant trait "flowering time" over 10 generations would determine early or late flowering in axenic Arabidopsis microcosms. Indeed, the plant-associated microbiome of plants is a heritable plant trait as evidenced in different plant-microbe systems. The efficiency of selection for microbiome-mediated resistance depends on the heritability of the trait (i.e., genotypic variance divided by phenotypic variance). The host plant phenotype $(P)$ is determined by the genotype $(\mathrm{G})$, the environment $(\mathrm{E})$, the genotype $\times$ environment interaction $(G \times E)$ and random effects (e). Integrating the soil microbiome into the formula results in $P=G+E$ (including microbiome) $+\mathrm{G} \times \mathrm{E}$ (including plant-microbe interaction and plant $\times$ microbe $\times \mathrm{E}$ interaction) $+\mathrm{e}$. Although breeders can utilize the variation based on $\mathrm{G}$, the microbiome is mainly determined by the environment (soil type and structure, $\mathrm{pH}$, climatic conditions, management practices), and the plant driven shift of microbial community is part of the $G \times E$ interaction. Part of $G \times E$ interactions that is linked to specific environmental factors such as soil type, climatic conditions, crop management, or microbial communities can be utilized in breeding for local adaptation (Annicchiarico, Bellah, \& Chiari, 2005; Busby et al., 2017). Likewise, breeding more diverse cropping systems (e.g., mixed cropping, intercropping, undersowing) that harbour and maintain greater microbial diversity (Chave, Tchamitchian, \& Ozier-Lafontaine, 2014; Granzow et al., 2017; Lori, Symnaczik, Mäder, De Deyn, \& Gattinger, 2017; Wang, Zheng, et al., 2017) will foster selection for beneficial plant microbe interaction.

Wagner et al. (2016) reported significant plant genotype effects and $G \times E$ interaction of wild perennial mustard (Boechera stricta) on the microbiome community of leaves as well as effect of the plant age. The authors stress the importance of replicating microbiome experiments across sites and time points, in order to reveal genes controlling microbiome variation that are of actual relevance for given farming environments. However, direct selection of plants promoting a beneficial soil microbiome community is very challenging, because few studies are available where microbial diversity is linked with improved plant health and because fields are not yet characterized according to their microbiome profile. In the future, further research of the soil microbiome and employment of additional tools like metagenome-wide association studies will allow to predict traits such as disease resistance based on the rhizosphere community composition (Chang et al., 2017; Nogales et al., 2016).

\subsection{Genetic markers for beneficial microbial communities}

As discussed in earlier sections, the plant genotype determines microbial community composition in the rhizosphere and this microbial community has direct implications for plant health. To take advantage of this knowledge and to integrate it into plant breeding, future research needs to explore which plant loci govern the interaction with the microbiome. In addition to illuminating the microbiome of different crop species and cultivars, the vast amount of microbiome sequencing data will allow to perform promising GWAS to identify plant loci responsible for specific plant-microbe interactions. In this regard, the work of Smith, Handelsman, and Goodman (1999) has pioneer character. They evaluated the efficacy of the biocontrol agent Bacillus cereus against the tomato seed pathogen Pythium torulosum and detected significant phenotypic variation among recombinant inbred tomato lines for B. cereus-mediated disease resistance. Genetic analysis revealed that three major QTL, associated with disease suppression by B. cereus, explained $38 \%$ of the observed phenotypic variation among the recombinant inbred lines. Horton et al. (2014) revealed that the microbial community of Arabidopsis is genotype-dependent and used a GWAS to identify plant loci responsible for the host genotype-dependent structuring of the microbial community. Intriguingly, gene sets involved in defence reaction and signal transduction in the plant were identified as being most important in the structuring of the microbial composition. With more and more genomic information available beyond model species (e.g., reference genome for common bean; Schmutz et al., 2014), the identification of genomic loci and candidate genes involved in plant-microbiome interactions will be possible for legume crop species as well. For instance, a publicly available SNP marker data set has recently been released for pea (Holdsworth et al., 2017) and chickpea (Parween et al., 2015). Association mapping has furthermore been successfully applied to identify markers for various agronomic important traits in legumes (Cheng et al., 2015; Zuiderveen, Padder, Kamfwa, Song, \& Kelly, 2016). Leveraging plant genomic resources together with metagenomic information of the associated microbiota would enable the identification of markers for resistance against soil-borne pathogen complexes and the application of MAS in breeding programmes in the future (Kroll, Agler, \& Kemen, 2017). This would ultimately lead to an enhancement of a favourable interplay between crop plants and their associated soil microbiota.

\section{7 | Plant selection based on key root exudates}

Root exudates are central elements in the dialogue between plants and the microbial community in the rhizosphere. Genetic variation in root exudate composition could be exploited in breeding programmes if certain key exudates can be linked to microbial-mediated disease resistance. Breeding lines can be screened for resistance on pathogen-infested soil. Subsequent profiling of root exudates using untargeted metabolomics (e.g., gas chromatography-mass spectrometry; Zhang, Sun, Wang, Han, \& Wang, 2012) will enable the identification of key metabolites or exudate profiles significantly associated with disease resistance. Pavan et al. (2016) found a pea cultivar highly resistant to broomrape infection and evidenced a reduced exudation of strigolactones as the explanation for resistance. However, strigolactones are also of great importance for AM symbiosis and care must be taken before such a selection target is chosen to avoid tradeoffs (Bakker et al., 2012). Parallel analysis of the microbiome 
composition allows to link plant resistance, root exudation profile, and the occurrence of key microbes responsible for plant health. For instance, Wu et al. (2017) showed that organic acids exuded by the herb Radix pseudostellariae have negative effects on biocontrol microbes but favour pathogenic fungi and bacteria. Association mapping can be applied to identify genes involved in the synthesis and regulation of such key root exudates. Thereby, plant breeders have an intermediary trait at their command that allows them to select for microbe-mediated disease resistance. Moreover, recent advances in omics technologies propel the ambition to engineer the plant rhizosphere for healthier and more productive crop plants (Ramalingam, Kudapa, Pazhamala, Weckwerth, \& Varshney, 2015; Zhang, RuyterSpira, \& Bouwmeester, 2015). This knowledge will be a valuable source of information for the design of molecular plant breeding strategies.

\section{5 | CONCLUDING REMARKS}

The importance of grain legumes for feed and food production is likely to increase in the near future. Rich in high quality proteins, minerals, and vitamins, they represent a healthy food component in human diet. In many developing countries, they are already an irreplaceable part of the daily dishes, and, in the lifestyle societies of industrialized countries, they contribute to a reduced meet consumption. Through the symbiotic association with $\mathrm{N}$-fixing rhizobia, legumes are able to significantly improve soil fertility, and hence, represent an ecologically important crop in low-input farming systems. Moreover, cool-season grain legumes provide an important alternative to soy-based protein imports. In the past decade, many reviews summarized the importance of microbial communities for plant health. Associations between roots and beneficial microorganisms, including the well-studied examples of symbiotic associations of legumes with rhizobia or AM symbiosis, form the basis of our current understanding of plant-microbe interactions. We can expect that we will be able to go beyond these reductionist approaches in the near future and that our knowledge on complex plant-microbiome interactions will grow. More and more experiments assess complex plant-microbe interactions in soil-based systems and we begin to elucidate how plants protect themselves by shaping the microbial complexity of the rhizosphere. The understanding of the chemical dialogue between plants and microbes along the genomic deciphering of microbiome compositions will reveal leveraging points for resilient crop production systems. Plant breeding is the means by which plant-microbiome interactions can be harnessed to shape healthy and beneficial microbial communities in the rhizosphere. Integrating the knowledge on multifunctional interactions between crop plants and microbes in future agricultural systems and plant breeding will eventually lead to sustainable solutions to reduce the threat imposed by soil-borne pathogens.

\section{ACKNOWLEDGMENTS}

We thank Anja Wille for creating Figure 1. The authors would like to thank the Mercator Research Program of the ETH Zürich World Food System Center and the ETH Zürich Foundation for supporting the project resPEAct. The authors wish to thank the Swiss Federal Office of Agriculture for financial support. This research has received funding from the European Union's Horizon 2020 research and innovation programme LIVESEED under Grant agreement 727230 and by the Swiss State Secretariat for Education, Research and Innovation (SERI) under contract number 17.00090. The information contained in this communication only reflects the author's view. Neither the Research Executive Agency nor SERI is responsible for any use that may be made of the information provided.

\section{ORCID}

Monika M. Messmer (10) http://orcid.org/0000-0002-6120-0079

Pierre Hohmann (D) http://orcid.org/0000-0001-7029-0566

\section{REFERENCES}

Abdel-Monaim, M. F., \& Abo-Elyousr, K. A. M. (2012). Effect of preceding and intercropping crops on suppression of lentil damping-off and root rot disease in New Valley - Egypt. Crop Protection, 32, 41-46.

Abdel-Monaim, M. F., Abo-Elyousr, K. A. M., \& Morsy, K. M. (2011). Effectiveness of plant extracts on suppression of damping-off and wilt diseases of lupine (Lupinus termis Forsik). Crop Protection, 30, 185-191.

Abdullah, A. S., Moffat, C. S., Lopez-Ruiz, F. J., Gibberd, M. R., Hamblin, J., \& Zerihun, A. (2017). Host-multi-pathogen warfare: Pathogen interactions in co-infected plants. Frontiers in Plant Science, 8, 1-12.

Abujabhah, I. S., Bound, S. A., Doyle, R., \& Bowman, J. P. (2016). Effects of biochar and compost amendments on soil physico-chemical properties and the total community within a temperate agricultural soil. Applied Soil Ecology, 98, 243-253.

Acquaah, G. (2012). Principles of plant genetics and breeding (Second ed.). John Wiley \& Sons, Ltd.

Aira, M., Gómez-Brandón, M., Lazcano, C., Bååth, E., \& Domínguez, J. (2010). Plant genotype strongly modifies the structure and growth of maize rhizosphere microbial communities. Soil Biology and Biochemistry, 42, 2276-2281.

Akhtar, M. S., \& Siddiqui, Z. A. (2009). Use of plant growth-promoting rhizobacteria for the biocontrol of root-rot disease complex of chickpea. Australasian Plant Pathology, 38, 44.

Akhter, W., Khurshed, M., Bhuiyan, A., Sultana, F., Bhuiyan, M. K. A., Sultana, F., \& Hossain, M. M. (2015). Integrated effect of microbial antagonist, organic amendment and fungicide in controlling seedling mortality (Rhizoctonia solani) and improving yield in pea (Pisum sativum L.). Comptes Rendus Biologies, 338, 21-28.

Alcala, A. V. C., Paulitz, T. C., Schroeder, K. L., Porter, L. D., Derie, M. L., \& du Toit, L. J. (2016). Pythium species associated with damping-off of pea in certified organic fields in the columbia basin of central Washington. Plant Disease, 100. PDIS-07-15-0774

Allen, D. J., \& Lenné, J. M. (1997). The pathology of food and pasture legumes. Wallingford, UK: CAB International and Hyderabad, India: ICRISAT.

An, G.-H., Kobayashi, S., Enoki, H., Sonobe, K., Muraki, M., Karasawa, T., \& Ezawa, T. (2009). How does arbuscular mycorrhizal colonization vary with host plant genotype? An example based on maize (Zea mays) germplasms. Plant and Soil, 327, 441-453.

Anderson, J., Wagner, M., Rushworth, C., Prasad, K., \& Mitchell-Olds, T. (2013). The evolution of quantitative traits in complex environments. Heredity, 112, 4-12.

Andreote, F. D., \& de Pereira e Silva, M. C. (2017). Microbial communities associated with plants: Learning from nature to apply it in agriculture. Current Opinion in Microbiology, 37, 29-34.

Annicchiarico, P., Bellah, F., \& Chiari, T. (2005). Defining subregions and estimating benefits for a specific-adaptation strategy by breeding programs: A case study. Crop Science, 45, 1741-1749. 
Aveskamp, M. M., de Gruyter, J., Woudenberg, J. H. C., Verkley, G. J. M., \& Crous, P. W. (2010). Highlights of the Didymellaceae: A polyphasic approach to characterise Phoma and related pleosporalean genera. Studies in Mycology, 65, 1-60.

Azevedo, D. M. Q., Rocha, F. S., Costa, C. A., Pfenning, L. H., da Costa, S. S., Melo, M. P., ... de Fernanades, M. F. G. (2017). Etiology of root rot and wilt disease of chickpea in Brazil. Tropical Plant Pathology, 42, 273-283.

Aziz, N. H., El-Fouly, M. Z., El-Essawy, A. A., \& Khalaf, M. A. (1997). Influence of bean seedling root exudates on the rhizosphere colonization by Trichoderma lignroum for the control of Rhizoctonia solani. Botanical Bulletin-Academia Sinica, 38, 33-39.

Babu, S., Bidyarani, N., Chopra, P., Monga, D., Kumar, R., Prasanna, R., ... Saxena, A. K. (2015). Evaluating microbe-plant interactions and varietal differences for enhancing biocontrol efficacy in root rot disease challenged cotton crop. European Journal of Plant Pathology, 142, 345-362.

Baćanović-Šišić, J., Šišić, A., Schmidt, J. H., \& Finckh, M. R. (2017). Identification and characterization of pathogens associated with root rot of winter peas grown under organic management in Germany. European Journal of Plant Pathology, 1-11.

Baetz, U., \& Martinoia, E. (2014). Root exudates: The hidden part of plant defense. Trends in Plant Science, 19, 90-98.

Bahramisharif, A., Lamprecht, S., Spies, C. F. J., Botha, W., Calitz, F. J., \& McLeod, A. (2014). Pythium spp. associated with rooibos seedlings and their pathogenicity towards rooibos, lupin and oat. Plant Disease, 223-232.

Bainard, L. D., Navarro-Borrell, A., Hamel, C., Braun, K., Hanson, K., \& Gan, Y. (2017). Increasing the frequency of pulses in crop rotations reduces soil fungal diversity and increases the proportion of fungal pathotrophs in a semiarid agroecosystem. Agriculture, Ecosystems and Environment, 240, 206-214.

Bais, H. P., Walker, T. S., Schweizer, H. P., \& Vivanco, J. M. (2002). Root specific elicitation and antimicrobial activity of rosmarinic acid in hairy root cultures of Ocimum basilicum. Plant Physiology and Biochemistry, 40, 983-995.

Bais, H. P., Weir, T. L., Perry, L. G., Gilroy, S., \& Vivanco, J. M. (2006). The role of root exudates in rhizosphere interactions with plants and other organisms. Annual Review of Plant Biology, 57, 233-266.

Bakker, M. G., Manter, D. K., Sheflin, A. M., Weir, T. L., \& Vivanco, J. M. (2012). Harnessing the rhizosphere microbiome through plant breeding and agricultural management. Plant and Soil, 360, 1-13.

Bardin, S. D., Huang, H.-C. C., Pinto, J., Amundsen, E. J., \& Erickson, R. S. (2004). Biological control of Pythium damping-off of pea and sugar beet by Rhizobium leguminosarum bv. viceae. Canadian Journal of Botany, 82, 291-296.

Barilli, E., Cobos, M. J., \& Rubiales, D. (2016). Clarification on host range of Didymella pinodes the causal agent of pea ascochyta blight. Frontiers in Plant Science, 7, 592.

Basu, P. K., Brown, N. J., Crête, R., \& Al, E. (1976). Yield loss conversion factors for fusarium root rot of pea. Canadian Plant Disease Survey, $56,25-32$.

Bazghaleh, N., Hamel, C., Gan, Y., Tar'an, B., \& Knight, J. D. (2015). Genotype-specific variation in the structure of root fungal communities is related to chickpea plant productivity. Applied and Environmental Microbiology, 81, 2368-2377.

Bennett A. E., Daniell T. J. \& White P. J. (2013) Benefits of breeding crops for yield response to soil organisms. In Molecular microbial ecology of the rhizosphere. (ed F.J. de Bruijn), pp. 17-27. Wiley \& Sons, Inc.

Berendsen, R. L., Pieterse, C. M. J., \& Bakker, P. a. H. M. (2012). The rhizosphere microbiome and plant health. Trends in Plant Science, 17, 478-486.

Berg, G., Köberl, M., Rybakova, D., Müller, H., Grosch, R., \& Smalla, K. (2017). Plant microbial diversity is suggested as the key to future biocontrol and health trends. FEMS Microbiology Ecology, 93.
Berg, L. E., Miller, S. S., Dornbusch, M. R., \& Samac, A. (2017). Seed rot and damping-off of alfalfa in Minnesota caused by Pythium and Fusarium species. Plant Disease, 101, 1860-1867.

Bodker, L., Kjoller, R., \& Rosendahl, S. (1998). Effect of phosphate and the arbuscular mycorrhizal fungus Glomus intraradices on disease severity of root rot of peas (Pisum sativum) caused by Aphanomyces euteiches. Mycorrhiza, 8, 169-174.

Borrell, A. N., Shi, Y., Gan, Y., Bainard, L. D., Germida, J. J., \& Hamel, C. (2017). Fungal diversity associated with pulses and its influence on the subsequent wheat crop in the Canadian prairies. Plant and Soil, 414, 13-31.

Brahmi, I., Mabrouk, Y., Brun, G., Delavault, P., Belhadj, O., \& Simier, P. (2016). Phenotypical and biochemical characterization of resistance for parasitic weed (Orobanche foetida Poir.) in radiation mutagenized mutants of chickpea. Pest Management Science, 72, 2330-2338.

Broeckling, C. D., Broz, A. K., Bergelson, J., Manter, D. K., \& Vivanco, J. M. (2008). Root exudates regulate soil fungal community composition and diversity. Applied and Environmental Microbiology, 74, 738-744.

Bulgarelli, D., Garrido-Oter, R., Münch, P. C., Weiman, A., Dröge, J., Pan, Y., ... Schulze-Lefert, P. (2015). Structure and function of the bacterial root microbiota in wild and domesticated barley. Cell Host \& Microbe, 17, 392-403.

Busby, P. E., Soman, C., Wagner, M. R., Friesen, M. L., Kremer, J., Bennett, A., ... Dangl, J. L. (2017). Research priorities for harnessing plant microbiomes in sustainable agriculture. PLoS Biology, 15, 1-14.

Cameron, D. D., Neal, A. L., van Wees, S. C. M. M., \& Ton, J. (2013). Mycorrhiza-induced resistance: More than the sum of its parts? Trends in Plant Science, 18, 539-545.

Carrillo, E., Rubiales, D., Pérez-de-Luque, A., \& Fondevilla, S. (2012). Characterization of mechanisms of resistance against Didymella pinodes in Pisum spp. European Journal of Plant Pathology, 135, 761-769.

Carrillo, E., Satovic, Z., Aubert, G., Boucherot, K., Rubiales, D., \& Fondevilla, S. (2014). Identification of quantitative trait loci and candidate genes for specific cellular resistance responses against Didymella pinodes in pea. Plant Cell Reports, 33, 1133-1145.

Carvalhais, L. C., Dennis, P. G., Badri, D. V., Kidd, B. N., Vivanco, J. M., \& Schenk, P. M. (2015). Linking Jasmonic acid signaling, root exudates, and rhizosphere microbiomes. Molecular Plant-Microbe Interactions, 28, 1049-1058.

Castillo, P., Navas-Cortés, J. A., Landa, B. B., Jiménez-Díaz, R. M., \& Vovlas, N. (2008). Plant-parasitic nematodes attacking chickpea and their in planta interactions with rhizobia and phytopathogenic fungi. Plant Disease, 92, 840-853.

Chandra, R., \& Kumar, R. (2008). Influence of PGPR and PSB on Rhizobium leguminosarum bv. viciae strain competition and symbiotic performance in lentil. World Journal of Agricultural Sciences, 4, 297-301.

Chang, H. X., Haudenshield, J. S., Bowen, C. R., \& Hartman, G. L. (2017). Metagenome-wide association study and machine learning prediction of bulk soil microbiome and crop productivity. Frontiers in Microbiology, 8, 1-11.

Chang, K. F., Hwang, S. F., Ahmed, H. U., Strelkov, S. E., Gossen, B. D., Turnbull, G. D., \& Blade, S. F. (2014). Disease reaction to Fusarium avenaceum and yield losses in narrow-leafed lupin lines. Canadian Journal of Plant Science, 94, 1211-1218.

Chang, K. F., Hwang, S. F., Wang, H., Gossen, B. D., Turnbull, G. D., \& Howard, R. J. (2006). Evaluation of field pea cultivars for resistance to root and stem rot and seedling blight caused by Rhizoctonia solani-Meeting abstract. Canadian Journal of Plant Science, 86, 190-190.

Chaparro, J. M., Badri, D. V., \& Vivanco, J. M. (2014). Rhizosphere microbiome assemblage is affected by plant development. The ISME Journal, 8, 790-803.

Chave, M., Tchamitchian, M., \& Ozier-Lafontaine, H. (2014). Agroecological engineering to biocontrol soil pests for crop health. (pp. 269-297) Springer, Cham. 
Cheng, P., Holdsworth, W., Ma, Y., Coyne, C. J., Mazourek, M., Grusak, M. A., ... McGee, R. J. (2015). Association mapping of agronomic and quality traits in USDA pea single-plant collection. Molecular Breeding, 35.

Chiang, C. C., \& Hadwiger, L. A. (1991). The Fusarium solani-induced expression of a pea gene family encoding high cysteine content proteins. Molecular Plant-Microbe Interactions, 4, 324-331.

Chittem, K., Mathew, F. M., Gregoire, M., Lamppa, R. S., Chang, Y. W. Markell, S. G., ... Goswami, R. S. (2015). Identification and characterization of Fusarium spp. associated with root rots of field pea in North Dakota. European Journal of Plant Pathology, 143, 641-649.

Cole, B. J., Feltcher, M. E., Waters, R. J., Wetmore, K. M., Mucyn, T. S., Ryan, E. M., ... Visel, A. (2017). Genome-wide identification of bacterial plant colonization genes. PLoS Biology, 15. e2002860

Coleman, J. J. (2016). The Fusarium solani species complex: Ubiquitous pathogens of agricultural importance. Molecular Plant Pathology, 17, 146-158.

Coleman-Derr, D., \& Tringe, S. G. (2014). Building the crops of tomorrow: Advantages of symbiont-based approaches to improving abiotic stress tolerance. Frontiers in Microbiology, 5, 283.

Conrath, U., Beckers, G. J. M., Flors, V., García-Agustín, P., Jakab, G., Mauch, F., ... Mauch-Mani, B. (2006). Priming: Getting ready for battle. Molecular Plant-Microbe Interactions, 19, 1062-1071.

Coyne, C. J., Pilet-Nayel, M.-L. L., McGee, R. J., Porter, L. D., Smýkal, P., \& Grünwald, N. J. (2015). Identification of QTL controlling high levels of partial resistance to Fusarium solani f. sp. pisi in pea. Plant Breeding, 134, 446-453.

Cruickshank, I. A. M., \& Perrin, D. R. (1960). Isolation of a Phytoalexin from Pisum sativum L. Nature, 187, 799-800.

Cui, R., Wang, H., Zeng, Y., \& Sun, X. (2016). Application of deep pyrosequencing to the analysis of soil microbial communities in different lotus fields. Journal of Residuals Science \& Technology, 13, S235-S241.

Curl, E., \& Truelove, B. (1986). Root exudates. In: The rhizosphere (pp. 55-92). Berlin-Heidelberg: Springer-Verlag.

Das, K., Prasanna, R., \& Saxena, A. K. (2017). Rhizobia: A potential biocontrol agent for soilborne fungal pathogens. Folia Microbiologica, 62, 425-435.

de Boer, W. (2017). Upscaling of fungal-bacterial interactions: From the lab to the field. Current Opinion in Microbiology, 37, 35-41.

Dehariya, K., Shukla, A., Sheikh, I. A., \& Vyas, D. (2015). Trichoderma and arbuscular mycorrhizal fungi based biocontrol of Fusarium udum butler and their growth promotion effects on pigeon pea. Journal of Agricultural Science and Technology, 17, 505-517.

Desalegn, G., Turetschek, R., Kaul, H. P., \& Wienkoop, S. (2016). Microbial symbionts affect Pisum sativum proteome and metabolome under Didymella pinodes infection. Journal of Proteomics, 143, 173-187.

Desgroux, A., Anthoëne, V. L., Roux-Duparque, M., Rivière, J., Aubert, G., Tayeh, N., ... Bourion, V. (2016). Genome-wide association mapping of partial resistance to Aphanomyces euteiches in pea. BMC Genomics, $1-21$.

Desgroux, A., Baudais, V. N., Aubert, V., Le Roy, G., de Larambergue, H. Miteul, H., ... Bourion, V. (2018). Comparative genome-wide-association mapping identifies common loci controlling root system architecture and resistance to Aphanomyces euteiches in pea. Frontiers in Plant Science, 8.

Doornbos, R. F., van Loon, L. C., \& Bakker, P. A. H. M. (2011). Impact of root exudates and plant defense signaling on bacterial communities in the rhizosphere. A review. Agronomy for Sustainable Development, 32 227-243.

Douglas, A. E., \& Werren, J. H. (2016). Holes in the hologenome: Why host-microbe symbioses are not holobionts. MBio, 7, 1-7.

Dubey, S. C., Tripathi, A., Upadhyay, B. K., \& Deka, U. K. (2014). Diversity of rhizoctonia solani associated with pulse crops in different agro-ecological regions of India. World Journal of Microbiology and Biotechnology, 30, 1699-1715.
Dudeja, S. S., Giri, R., Saini, R., Suneja-Madan, P., \& Kothe, E. (2012). Interaction of endophytic microbes with legumes. Journal of Basic Microbiology, 52, 248-260.

Dutta, S., Morang, P., Nishanth Kumar, S., \& Dileep Kumar, B. S. (2014) Fusarial wilt control and growth promotion of pigeon pea through bioactive metabolites produced by two plant growth promoting rhizobacteria. World Journal of Microbiology and Biotechnology, 30, 1111-1121.

Edwards, J., Johnson, C., Santos-Medellín, C., Lurie, E., Podishetty, N. K., Bhatnagar, S., ... Sundaresan, V. (2015). Structure, variation, and assembly of the root-associated microbiomes of rice. Proceedings of the National Academy of Sciences, 112, E911-E920.

Egamberdieva, D., Wirth, S. J., Shurigin, V. V., Hashem, A., \& Abd_Allah, E. F. (2017). Endophytic bacteria Improve plant growth, symbiotic performance of chickpea (Cicer arietinum L.) and induce suppression of root rot caused by Fusarium solani under salt stress. Frontiers in Microbiology, 8, 1887.

Ellouze, W., Hamel, C., Vujanovic, V., Gan, Y., Bouzid, S., \& St-Arnaud, M. (2013). Chickpea genotypes shape the soil microbiome and affect the establishment of the subsequent durum wheat crop in the semiarid North American Great Plains. Soil Biology and Biochemistry, 63, 129-141.

Emden, H. F., Ball, S. L., \& Rao, M. R. (1988). Pest, disease and weed problems in pea, lentil, faba bean and chickpea. In R. J. Summerfield (Ed.), World crops: Cool season food legumes. Current plant science and biotechnology in agriculture (pp. 519-534). Dordrecht: Springer.

Emmett, B. D., Youngblut, N. D., Buckley, D. H., \& Drinkwater, L. E. (2017). Plant phylogeny and life history shape rhizosphere bacterial microbiome of summer annuals in an agricultural field. Frontiers in Microbiology, 8, 2414.

Enkerli, J., Bhatt, G., \& Covert, S. F. (1998). Maackiain detoxification contributes to the virulence of Nectria haematococca MP VI on chickpea. Molecular Plant-Microbe Interactions, 11, 317-326.

Evidente, A., Fernández-Aparicio, M., Cimmino, A., Rubiales, D., Andolfi, A., \& Motta, A. (2009). Peagol and peagoldione, two new strigolactone-like metabolites isolated from pea root exudates. Tetrahedron Letters, 50 6955-6958.

FAOSTAT (2016) Food and agricultural organization of the United Nations. Available online at: http://faostat.fao.org/site/567/DesktopDefault.aspx? PagelD=567\#ancor (Accessed 12.11.17)

Feng, J., Hwang, R., Chang, K. F., Conner, R. L., Hwang, S. F., Strelkov, S. E., ... Xue, A. G. (2011). Identification of microsatellite markers linked to quantitative trait loci controlling resistance to Fusarium root rot in field pea. Canadian Journal of Plant Science, 91, 199-204.

Feng, J., Hwang, R., Chang, K. F., Hwang, S. F., Strelkov, S. E., Gossen, B. D., ... Turnbull, G. D. (2009). Fusarium avenaceum is the major pathogen causing Fusarium root rot on Alberta field pea. Canadian Journal of Plant Pathology, 31, 483.

Finkel, O. M., Castrillo, G., Herrera Paredes, S., Salas González, I., \& Dangl, J. L. (2017). Understanding and exploiting plant beneficial microbes. Current Opinion in Plant Biology, 38, 155-163.

Fließbach, A., Winkler, M., Lutz, M. P., Oberholzer, H.-R., \& Mäder, P. (2009). Soil amendment with Pseudomonas fluorescens CHAO: Lasting effects on soil biological properties in soils low in microbial biomass and activity. Microbial Ecology, 57, 611-623.

Fondevilla, S., Almeida, N. F., Satovic, Z., Rubiales, D., Vaz Patto, M. C., Cubero, J. I., \& Torres, A. M. (2011). Identification of common genomic regions controlling resistance to Mycosphaerella pinodes, earliness and architectural traits in different pea genetic backgrounds. Euphytica, 182, 43-52.

Fondevilla, S., Satovic, Z., Rubiales, D., Moreno, M. T., \& Torres, A. M. (2007). Mapping of quantitative trait loci for resistance to Mycosphaerella pinodes in Pisum sativum subsp. syriacum. Molecular Breeding, 21, 439-454.

Foo, E., \& Reid, J. B. (2012). Strigolactones: New physiological roles for an ancient signal. Journal of Plant Growth Regulation, 32, 429-442. 
Foyer, C. H., Lam, H.-M., Nguyen, H. T., Siddique, K. H. M., Varshney, R. K. Colmer, T. D., ... Considine, M. J. (2016). Neglecting legumes has compromised human health and sustainable food production. Nature Plants, 2, 1-10.

Fuchs, J. G., Thuerig, B., Brandhuber, R., Bruns, C., Finckh, M. R., Fliessbach, A., ... Lucius, T. (2014). Evaluation of the causes of legume yield depression syndrome using an improved diagnostic tool. Applied Soil Ecology, 79, 26-36.

Gao, X., Lu, X., Wu, M., Zhang, H., Pan, R., Tian, J., ... Liao, H. (2012). Coinoculation with Rhizobia and AMF inhibited soybean red crown rot: From field study to plant defense-related gene expression analysis. PLoS One, 7, e33977.

Garbeva, P., van Elsas, J. D., \& van Veen, J. A. (2007). Rhizosphere microbial community and its response to plant species and soil history. Plant and Soil, 302, 19-32.

Garg N. \& Geetanjali (2007). Symbiotic nitrogen fixation in legume nodules: Process and signaling. A review. Agronomy for Sustainable Development 27, 59-68.

Gaue, R. (1998). Ergebnisse und methoden der rotkleezüchtung in malchow auf der insel poel*. Archives of Agronomy and Soil Science, 43, 93-108.

Gaulin, E., Jacquet, C., Bottin, A., \& Dumas, B. (2007). Root rot disease of legumes caused by Aphanomyces euteiches. Molecular Plant Pathology, $8,539-548$

Gilbert, J. A., Quinn, R. A., Debelius, J., Xu, Z. Z., Morton, J., Garg, N., ... Knight, R. (2016). Microbiome-wide association studies link dynamic microbial consortia to disease. Nature, 535, 94-103.

Giri, A. P., Harsulkar, A. M., Patankar, A. G., Gupta, V. S., Sainani, M. N., Deshpande, V. V., \& Ranjekar, P. K. (1998). Association of induction of protease and chitinase in chickpea roots with resistance to Fusarium oxysporum f.sp. ciceri. Plant Pathology, 47, 693-699.

Gomez-Roldan, V., Fermas, S., Brewer, P. B., Puech-Pagès, V., Dun E. a, Pillot, J.-P., ... Rochange, S. F. (2008) Strigolactone inhibition of shoot branching. Nature 455, 189-194.

Gopal, M., Gupta, A., \& Thomas, G. V. (2013). Bespoke microbiome therapy to manage plant diseases. Frontiers in Microbiology, 4.

Goswami, R. S., Dong, Y., Punja, Z. K., Goswami, R. S., Punja, Z. K., \& Dong, Y. (2008). Host range and mycotoxin production by Fusarium equiseti isolates originating from ginseng fields. Canadian Journal of Plant Pathology, 30, 155-160.

Graham, P. H., \& Vance, C. P. (2003). Legumes: Importance and constraints to greater use. Plant Physiology, 131, 872-877.

Granzow, S., Kaiser, K., Wemheuer, B., Pfeiffer, B., Daniel, R., Vidal, S., \& Wemheuer, F. (2017). The effects of cropping regimes on fungal and bacterial communities of wheat and faba bean in a greenhouse pot experiment differ between plant species and compartment. Frontiers in Microbiology, 8, 902.

Grünwald, N. J., Coffman, V. a, Kraft, J. M., Grunwald, N. J., Coffman, V. a, Kraft, J. M., ... Kraft, J. M. (2003) Sources of partial resistance to Fusarium root rot in the pisum core collection. Plant Disease 87, 1197-1200.

Gu, Y.-H., \& Mazzola, M. (2003). Modification of fluorescent pseudomonad community and control of apple replant disease induced in a wheat cultivar-specific manner. Applied Soil Ecology, 24, 57-72.

Hadwiger, L. A. (2008). Pea-Fusarium solani interactions contributions of a system toward understanding disease resistance. Phytopathology, 98 , 372-379.

Hadwiger, L. A. (2015). Anatomy of a nonhost disease resistance response of pea to Fusarium solani: PR gene elicitation via DNase, chitosan and chromatin alterations. Frontiers in Plant Science, 6, 1-11.

Hagerty, C. H., Cuesta-Marcos, A., Cregan, P. B., Song, Q., McClean, P., Noffsinger, S., \& Myers, J. R. (2015). Mapping and root rot resistance and root architecture Quantitative Trait Loci in common bean. Crop Science, 55, 1969-1977.
Hale, I. L., Broders, K., \& Iriarte, G. (2014). A Vavilovian approach to discovering crop-associated microbes with potential to enhance plant immunity. Frontiers in Plant Science, 5, 492.

Hamon, C., Baranger, A., Coyne, C. J., McGee, R. J., Le Goff, I., L'Anthoëne, V., ... Pilet-Nayel, M. L. (2011). New consistent QTL in pea associated with partial resistance to Aphanomyces euteiches in multiple French and American environments. Theoretical and Applied Genetics, 123, 261-281.

Hamon, C., Coyne, C. J., McGee, R. J., Lesné, A., Esnault, R., Mangin, P., ... Pilet-Nayel, M.-L. (2013). QTL meta-analysis provides a comprehensive view of loci controlling partial resistance to Aphanomyces euteiches in four sources of resistance in pea. BMC Plant Biology, 13, 45.

Hanks, J. N., Snyder, A. K., Graham, M. A., Shah, R. K., Blaylock, L. A., Harrison, M. J., \& Shah, D. M. (2005). Defensin gene family in Medicago truncatula: structure, expression and induction by signal molecules. Plant Molecular Biology, 58, 385-399.

Harman, G. E., Howell, C. R., Viterbo, A., Chet, I., \& Lorito, M. (2004). Trichoderma species-Opportunistic, avirulent plant symbionts. Nature Reviews. Microbiology, 2, 43-56.

Hartman, K., van der Heijden, M. G., Roussely-Provent, V., Walser, J.-C., \& Schlaeppi, K. (2017). Deciphering composition and function of the root microbiome of a legume plant. Microbiome, 5, 2.

Hartmann, A., Rothballer, M., \& Schmid, M. (2008). Lorenz Hiltner, a pioneer in rhizosphere microbial ecology and soil bacteriology research. Plant and Soil, 312, 7-14.

Hartmann, A., Schmid, M., van, T. D., Berg, G., van Tuinen, D., \& Berg, G. (2009). Plant-driven selection of microbes. Plant and Soil, 321, 235-257.

Haware, M. P. (1981). Phoma blight - A new disease of chickpea. Plant Disease, 65, 282.

Haware, M. P., \& Nene, Y. L. (1984). The role of chickpea root exudates in resistance to Fusarium wilt. International Chickpea Newsletter, 10, 12-13.

Hetrick, B. a. D., Wilson, G. W. T., \& Todd, T. C. (1996). Mycorrhizal response in wheat cultivars: Relationship to phosphorus. Canadian Journal of Botany, 74, 19-25.

Heymann, F. (2008). Root rot of pea caused by Aphanomyces euteiches. Doctoral Thesis. Uppsala. Acta Universitatis agriculturae Sueciae, 24, 1652-6880.

Hilou, A., Zhang, H., Franken, P., \& Hause, B. (2014). Do jasmonates play a role in arbuscular mycorrhiza-induced local bioprotection of Medicago truncatula against root rot disease caused by Aphanomyces euteiches? Mycorrhiza, 24, 45-54.

Hiltpold, I., Jaffuel, G., \& Turlings, T. C. J. (2015). The dual effects of root-cap exudates on nematodes: From quiescence in plant-parasitic nematodes to frenzy in entomopathogenic nematodes. Journal of Experimental Botany, 66, 603-611.

Hirschi, K., \& Van Etten, H. D. (1996). Expression of the pisatin detoxifying genes (PDA) of Nectria haematococca in vitro and in planta. Molecular Plant-Microbe Interactions, 9, 483-491.

Hohmann, P., Jones, E. E., Hill, R. A., \& Stewart, A. (2011). Understanding Trichoderma in the root system of Pinus radiata: Associations between rhizosphere colonisation and growth promotion for commercially grown seedlings. Fungal Biology, 115, 759-767.

Hohmann, P., Jones, E. E., Hill, R. A., \& Stewart, A. (2012). Ecological studies of the bio-inoculant Trichoderma hamatum LU592 in the root system of Pinus radiata. FEMS Microbiology Ecology, 80, 709-721.

Hohmann, P., \& Messmer, M. M. (2017). Breeding for mycorrhizal symbiosis: Focus on disease resistance. Euphytica, 213, 1-11.

Holdsworth, W. L., Gazave, E., Cheng, P., Myers, J. R., Gore, M. A., Coyne, C. J., ... Mazourek, M. (2017). A community resource for exploring and utilizing genetic diversity in the USDA pea single plant plus collection. Horticulture Research, 4. 17017

Horton, M. W., Bodenhausen, N., Beilsmith, K., Meng, D., Muegge, B. D., Subramanian, S., ... Bergelson, J. (2014). Genome-wide association study of Arabidopsis thaliana leaf microbial community. Nature Communications, 5, 5320. 
Hossain, S., Bergkvist, G., Berglund, K., Mårtensson, A., \& Persson, P. (2012). Aphanomyces pea root rot disease and control with special reference to impact of Brassicaceae cover crops. Acta Agriculturae Scandinavica Section B Soil and Plant Science, 62, 477-487.

Hsieh, T. F., Huang, H. C., \& Erickson, R. S. (2005). Biological control of bacterial wilt of bean using a bacterial endophyte, Pantoea agglomerans. Journal of Phytopathology, 153, 608-614.

Hu, J., Wei, Z., Weidner, S., Friman, V.-P., Xu, Y.-C., Shen, Q.-R., \& Jousset, A. (2017). Probiotic Pseudomonas communities enhance plant growth and nutrient assimilation via diversity-mediated ecosystem functioning. Soil Biology and Biochemistry, 113, 122-129.

Huang, H. C., \& Erickson, R. S. (2007). Effect of seed treatment with Rhizobium leguminosarum on Pythium damping-off, seedling height, root nodulation, root biomass, shoot biomass, and seed yield of pea and lentil. Journal of Phytopathology, 155, 31-37.

Huang, L. F., Song, L. X., Xia, X. J., Mao, W. H., Shi, K., Zhou, Y. H., \& Yu, J. Q. (2013). Plant-soil feedbacks and soil sickness: From mechanisms to application in agriculture. Journal of Chemical Ecology, 39, 232-242.

Hwang, S. F., Chang, K. F., Strelkov, S. E., Gossen, B. D., \& Howard, R. J. (2014). The impact of Fusarium avenaceum on lupin production on the Canadian prairies. Canadian Journal of Plant Pathology, 36, 291-299.

Infantino, A., Kharrat, M., Riccioni, L., Coyne, C. J., McPhee, K. E., \& Grünwald, N. J. (2006). Screening techniques and sources of resistance to root diseases in cool season food legumes. Euphytica, 147, 201-221.

Ingram, D. M., \& Cook, R. J. (1990). Pathogenicity of four Pythium species to wheat, barley, peas and lentils. Plant Pathology, 39, 110-117.

Johnston-Monje, D., Lundberg, D. S., Lazarovits, G., Reis, V. M., \& Raizada, M. N. (2016). Bacterial populations in juvenile maize rhizospheres originate from both seed and soil. Plant and Soil, 405, 337-355.

Johnston-Monje, D., Mousa, W. K., Lazarovits, G., \& Raizada, M. N. (2014). Impact of swapping soils on the endophytic bacterial communities of pre-domesticated, ancient and modern maize. BMC Plant Biology, 14.

Jones, D. L., Hodge, A., \& Kuzyakov, Y. (2004). Plant and mycorrhizal regulation of rhizodeposition. New Phytologist, 163, 459-480.

Kamilova, F., Kravchenko, L. V., Shaposhnikov, A. I., Azarova, T., Makarova, N., \& Lugtenberg, B. (2006). Organic acids, sugars, and L-tryptophane in exudates of vegetables growing on stonewool and their effects on activities of rhizosphere bacteria. Molecular Plant-Microbe Interactions, 19, 250-256.

Kamilova, F., Kravchenko, L. V., Shaposhnikov, A. I., Makarova, N., \& Lugtenberg, B. (2006). Effects of the tomato pathogen Fusarium oxysporum f. sp. radicis-lycopersici and of the biocontrol bacterium Pseudomonas fluorescens WCS365 on the composition of organic acids and sugars in tomato root exudate. Molecular Plant-Microbe Interactions, 19, 1121-1126.

Karkanis, A., Ntatsi, G., Kontopoulou, C. K., Pristeri, A., Bilalis, D., \& Savvas, D. (2016). Field Pea in European cropping systems: Adaptability, biological nitrogen fixation and cultivation practices. Notulae Botanicae Horti Agrobotanici Cluj-Napoca, 44, 325-336.

Katan, J. (2017). Diseases caused by soilborne pathogens: Biology, management and challenges. Journal of Plant Pathology, 99, 305-315.

Kato, K., \& Arima, Y. (2006). Potential of seed and root exudates of the common bean Phaseolus vulgaris $L$. for immediate induction of rhizobial chemotaxis and nod genes. Soil Science \& Plant Nutrition, 52, 432-437.

Kerr, A. (1963). The root rot-fusarium wilt complex of peas. Australian Journal of Biological Sciences, 16, 55-69.

Khan, T. N., Timmerman-Vaughan, G. M., Rubiales, D., Warkentin, T. D., Siddique, K. H. M., Erskine, W., \& Barbetti, M. J. (2013). Didymella pinodes and its management in field pea: Challenges and opportunities. Field Crops Research, 148, 61-77.

Kraft, J. M. (1977). The role of delphinidin and sugars in the resistance of pea seedlings to Fusarium root rot. Phytopathology, 67, 1057-1061.

Kraft, J. M., Dunne, B., Goulden, D., \& Armstrong, S. (1998). A Search for resistance in peas to Mycosphaerella pinodes. Plant Disease, 82, 251-253.
Kraft, J. M., \& Pfleger, F. L. (2001). Compendium of pea diseases and pests. Second Edi: American Phytopathological Society (APS Press).

Kroll, S., Agler, M. T., \& Kemen, E. (2017). Genomic dissection of hostmicrobe and microbe-microbe interactions for advanced plant breeding. Current Opinion in Plant Biology, 36, 71-78.

Kumar, J., Kaiser, W. J., \& Hannan, R. M. (1992). Damping-off resistance in chickpeas. Plant Disease, 75, 1244-1245.

Lakshmanan, V. (2015). Root microbiome assemblage is modulated by plant host factors. In Advances in botanical research (pp. 57-79). Elsevier Ltd.

Lamichhane, J. R., \& Venturi, V. (2015). Synergisms between microbial pathogens in plant disease complexes: A growing trend. Frontiers in Plant Science, 6, 1-12.

Lareen, A., Burton, F., \& Schäfer, P. (2016). Plant root-microbe communication in shaping root microbiomes. Plant Molecular Biology, 90, 575-587.

Leff, J. W., Lynch, R. C., Kane, N. C., \& Fierer, N. (2017). Plant domestication and the assembly of bacterial and fungal communities associated with strains of the common sunflower, Helianthus annuus. New Phytologist, 214, 412-423.

Leisso, R., Rudell, D., \& Mazzola, M. (2017). Metabolic composition of apple rootstock rhizodeposits differs in a genotype-specific manner and affects growth of subsequent plantings. Soil Biology and Biochemistry, 113, 201-214.

Li, W. J., Feng, J., Chang, K. F., Conner, R. L., Hwang, S. F., Strelkov, S. E., ... McLaren, D. L. (2012). Microsatellite DNA markers indicate quantitative trait loci controlling resistance to pea root rot caused by Fusarium avenaceum (Corda ex Fries) sacc. Plant Pathology Journal, 11, 114-119.

Li, X., Ding, C., Hua, K., Zhang, T., Zhang, Y., Zhao, L., ... Wang, X. (2014). Soil sickness of peanuts is attributable to modifications in soil microbes induced by peanut root exudates rather than to direct allelopathy. Soil Biology and Biochemistry, 78, 149-159.

Li, X. G., Zhang, T. L., Wang, X. X., Hua, K., Zhao, L., \& Han, Z. M. (2013). The composition of root exudates from two different resistant peanut cultivars and their effects on the growth of soil-borne pathogen. International Journal of Biological Sciences, 9, 164-173.

Li, Y., Huang, F., Lu, Y., Shi, Y., Zhang, M., Fan, J., \& Wang, W. (2013). Mechanism of plant-microbe interaction and its utilization in diseaseresistance breeding for modern agriculture. Physiological and Molecular Plant Pathology, 83, 51-58.

Li, Y. G., Zhang, S. Q., Sun, L. P., Li, S., \& Ji, P. (2017). First report of root rot of cowpea caused by Fusarium equiseti in Georgia in the United States. Plant Disease, 101, 1674-1674.

Li, Y. P., You, M. P., Norton, S., \& Barbetti, M. J. (2016). Resistance to Pythium irregulare root and hypocotyl disease in diverse common bean (Phaseolus vulgaris) varieties from 37 countries and relationships to waterlogging tolerance and other plant and seed traits. European Journal of Plant Pathology, 146, 147-176.

Lopes, R. B. M., de Oliveira Costa, L. E., Vanetti, M. C. D., de Araújo, E. F., \& de Queiroz, M. V. (2015). Endophytic bacteria isolated from common bean (Phaseolus vulgaris) exhibiting high variability showed antimicrobial activity and quorum sensing inhibition. Current Microbiology, 71, 509-516.

Lori, M., Symnaczik, S., Mäder, P., De Deyn, G., \& Gattinger, A. (2017). Organic farming enhances soil microbial abundance and activity-A meta-analysis and meta-regression. PLoS ONE, 12. e0180442

Lupwayi, N. Z., \& Kennedy, A. C. (2007). Grain legumes in Northern Great Plains: Impacts on selected biological soil processes. Agronomy Journal, 99, 1700-1709.

Mabrouk, Y., Simier, P., Arfaoui, A., Sifi, B., Delavault, P., Zourgui, L., \& Belhadj, O. (2007). Induction of phenolic compounds in pea (Pisum sativum L.) inoculated by Rhizobium leguminosarum and infected with Orobanche crenata. Journal of Phytopathology, 155, 728-734. 
Malvick, D. K., \& Percich, J. A. (1999). Identification of Pisum sativum germ plasm with resistance to root rot caused by multiple strains of Aphanomyces euteiches. Plant Disease, 83, 51-54.

Mark, G. L., \& Cassells, A. C. (1996). Genotype-dependence in the interaction between Glomus fistulosum, Phytophthora fragariae and the wild strawberry (Fragaria vesca). Plant and Soil, 185, 233-239.

Mathew, F. M., Lamppa, R. S., Chittem, K., Chang, Y. W., Botschner, M., Kinzer, K., ... Markell, S. G. (2012). Characterization and pathogenicity of Rhizoctonia solani isolates affecting Pisum sativum in North Dakota. Plant Disease, 96, 666-672.

Mathews, C., Ogola, J. B. O., Botha, W., Magongwa, M., \& Gaur, P. (2016). First report of root rot caused by Pythium spp. on chickpea in South Africa. Acta Agriculturae Scandinavica Section B: Soil and Plant Science, 66, 379-380.

McCoy, R. J., \& Kraft, J. M. (1984). Comparison of techniques and inoculum sources in evaluating pea (Pisum sativum) for resitance to stem rot caused by Rhizoctonia solani. Plant Disease, 68, 53-55.

Melzer, M. S., Yu, H., Labun, T., Dickson, A., \& Boland, G. J. (2016). Characterization and pathogenicity of Rhizoctonia spp. from field crops in Canada. Canadian Journal of Plant Pathology, 38, 367-374.

Mendes, R., Garbeva, P., \& Raaijmakers, J. M. (2013). The rhizosphere microbiome: Significance of plant beneficial, plant pathogenic, and human pathogenic microorganisms. FEMS Microbiology Reviews, 37, 634-663.

Meyer, J. B., Lutz, M. P., Frapolli, M., Péchy-Tarr, M., Rochat, L., Keel, C., ... Maurhofer, M. (2010). Interplay between wheat cultivars, biocontrol pseudomonads, and soil. Applied and Environmental Microbiology, 76, 6196-6204

Micallef, S. A., Shiaris, M. P., \& Colón-Carmona, A. (2009). Influence of Arabidopsis thaliana accessions on rhizobacterial communities and natural variation in root exudates. Journal of Experimental Botany, 60, 1729-1742.

Milani, N. A., Lawrence, D. P., Arnold, A. E., \& VanEtt (2012). Origin of pisatin demethylase (PDA) in the genus Fusarium. Fungal Genetics and Biology, 49, 933-942.

Misk, A., \& Franco, C. (2011). Biocontrol of chickpea root rot using endophytic actinobacteria. BioControl, 56, 811-822.

Mnasri, N., Chennaoui, C., Gargouri, S., Mhamdi, R., Hessini, K., Elkahoui, S., \& Djébali, N. (2017). Efficacy of some rhizospheric and endophytic bacteria in vitro and as seed coating for the control of Fusarium culmorum infecting durum wheat in Tunisia. European Journal of Plant Pathology, $147,501-515$.

Morgan, J. A. W., Bending, G. D., \& White, P. J. (2005). Biological costs and benefits to plant-microbe interactions in the rhizosphere. Journal of Experimental Botany, 56, 1729-1739.

Moussart, A., Even, M. N., Lesné, A., \& Tivoli, B. (2013). Successive legumes tested in a greenhouse crop rotation experiment modify the inoculum potential of soils naturally infested by Aphanomyces euteiches. Plant Pathology, 62, 545-551.

Muehlbauer, F. J., \& Chen, W. (2007). Resistance to ascochyta blights of cool season food legumes. European Journal of Plant Pathology, 119, 135-141.

Müller, D. B., Vogel, C., Bai, Y., \& Vorholt, J. A. (2016). The plant microbiota: Systems-level insights and perspectives. Annual Review of Genetics, 50, 211-234.

Nakedde, T., Ibarra-Perez, F. J., Mukankusi, C., Waines, J. G., \& Kelly, J. D. (2016). Mapping of QTL associated with Fusarium root rot resistance and root architecture traits in black beans. Euphytica, 212, 1-13.

Navarro, F., Sass, M. E., \& Nienhuis, J. (2008). Identification and confirmation of quantitative trait loci for root rot resistance in snap bean. Crop Science, 48, 962-972.

Nayyar, A., Hamel, C., Lafond, G., Gossen, B. D., Hanson, K., \& Germida, J. (2009). Soil microbial quality associated with yield reduction in continuous-pea. Applied Soil Ecology, 43, 115-121.
Nelson, E. B., Harman, G. E., \& Nash, G. T. (1988). Enhancement of Trichoderma-induced biological control of pythium seed rot and preemergence damping-off of peas. Soil Biology and Biochemistry, 20, $145-150$

Nene, Y. L., Reddy, M. V., Haware, M. P., \& Ghanekar, A. M. (2012). Field diagnosis of chickpea diseases and their control-Information Bulletin No. 28. Patancheru, India: International Crops Research Institute for the Semi-Arid Tropics.

Niu, B., Paulson, J. N., Zheng, X., \& Kolter, R. (2017). Simplified and representative bacterial community of maize roots. Proceedings of the National Academy of Sciences, 114, E2450-E2459.

Nóbrega, F. M., Santos, I. S., Da Cunha, M., Carvalho, A. O., Gomes, V. M., Nobrega, F. M., ... Gomes, V. M. (2005). Antimicrobial proteins from cowpea root exudates: Inhibitory activity against Fusarium oxysporum and purification of a chitinase-like protein. Plant and Soil, 272, 223-232.

Nogales, A., Nobre, T., Valadas, V., Ragonezi, C., Doring, M., Polidoros, A., \& Arnholdt-Schmitt, B. (2016). Can functional hologenomics aid tackling current challenges in plant breeding? Briefings in Functional Genomics, 15, 288-297.

Nzungize, J., \& Lyumugabe, F. (2012). Pythium root rot of common bean: Biology and control methods. A review. Biotechnology, Agronomy, Society and Environment, 16, 405-413.

O'Callaghan, M. (2016). Microbial inoculation of seed for improved crop performance: Issues and opportunities. Applied Microbiology and Biotechnology, 100, 5729-5746.

Ohh, S. H., King, T. H., \& Kommedahl, T. (1978). Evaluating peas for resistance to damping-off and root-rot caused by Pythium ultimum. Phytopathology, 68, 1644-1649.

Oliveira, R. S., Carvalho, P., Marques, G., Ferreira, L., Nunes, M., Rocha, I., ... Freitas, H. (2017). Increased protein content of chickpea (Cicer arietinum L.) inoculated with arbuscular mycorrhizal fungi and nitrogen-fixing bacteria under water deficit conditions. Journal of the Science of Food and Agriculture, 97, 4379-4385.

Oyarzun, P. J., Postma, J., Luttikholt, A. J. G., \& Hoogland, A. E. (1994). Biological control of foot and root rot in pea caused by Fusarium solani with nonpathogenic Fusarium oxysporum isolates. Canadian Journal of Botany, 72, 843-852.

Oyserman, B. O., Medema, M. H., \& Raaijmakers, J. M. (2018). Road MAPs to engineer host microbiomes. Current Opinion in Microbiology, $43,46-54$

Palmieri, D., Vitullo, D., de Curtis, F., \& Lima, G. (2017). A microbial consortium in the rhizosphere as a new biocontrol approach against fusarium decline of chickpea. Plant and Soil, 412, 425-439.

Panke-Buisse, K., Poole, A. C., Goodrich, J. K., Ley, R. E., \& Kao-Kniffin, J. (2014). Selection on soil microbiomes reveals reproducible impacts on plant function. The ISME Journal, 9, 980-989.

Parween, S., Nawaz, K., Roy, R., Pole, A. K., Venkata Suresh, B., Misra, G., ... Chattopadhyay, D. (2015). An advanced draft genome assembly of a Desi type chickpea (Cicer arietinum L.). Scientific Reports, 5, 1-14.

Patil, C. R., \& Alagawadi, A. R. (2010). Microbial inoculants for sustainable legume production. In Microbes for legume improvement (pp. 515-536). Springer, Vienna.

Pavan, S., Schiavulli, A., Marcotrigiano, A. R., Bardaro, N., Bracuto, V., Ricciardi, F., ... Ricciardi, L. (2016). Characterization of lowstrigolactone germplasm in pea (Pisum sativum L.) resistant to crenate broomrape (Orobanche crenata Forsk). Molecular Plant-Microbe Interactions, 29, 743-749.

Peiffer, J. A., Spor, A., Koren, O., Jin, Z., Green, S., Dangl, J. L., ... Ley, R. E. (2013). Diversity and heritability of the maize rhizosphere microbiome under field conditions. Proceedings of the National Academy of Sciences, 110, 6548-6553.

Pérez-Jaramillo, J. E., Carrión, V. J., Bosse, M., Ferrão, L. F. V., De Hollander, M., Garcia, A. A. F., ... Raaijmakers, J. M. (2017). Linking rhizosphere microbiome composition of wild and domesticated Phaseolus 
vulgaris to genotypic and root phenotypic traits. ISME Journal, 11, 2244-2257.

Pérez-Jaramillo, J. E., Mendes, R., \& Raaijmakers, J. M. (2016). Impact of plant domestication on rhizosphere microbiome assembly and functions. Plant Molecular Biology, 90, 635-644.

Peters, R. D., \& Grau, C. R. (2002). Inoculation with nonpathogenic Fusarium solani increases severity of pea root rot caused by Aphanomyces euteiches. Plant Disease, 86, 411-414.

Pfender, W. F., \& Hagedorn, D. J. (1982). Comparative virulence of Aphanomyces euteiches f. sp. phaseoli and Pythium ultimum on Phaseolus vulgaris at naturally occurring inoculum levels. Phytopathology, 72, 1200-1204.

Pflughöft, O. (2012). Zur Verbreitung und Bedeutung von Pilzkrankheiten in Körnerfuttererbsen (Pisum sativumi L.) in Deutschland. Gesunde Pflanzen, 64, 39-48.

Picard, C., Baruffa, E., \& Bosco, M. (2008). Enrichment and diversity of plant-probiotic microorganisms in the rhizosphere of hybrid maize during four growth cycles. Soil Biology and Biochemistry, 40, 106-115.

Pieterse, C. M. J., de Jonge, R., \& Berendsen, R. L. (2016). The soil-borne supremacy. Trends in Plant Science, 21, 171-173.

Pieterse, C. M. J., Zamioudis, C., Berendsen, R. L., Weller, D. M., Van Wees, S. C. M., \& Bakker, P. A. H. M. (2014). Induced systemic resistance by beneficial microbes. Annual Review of Phytopathology, 52, 347-375.

Pilet-Nayel, L., Muehlbauer, F. J., McGee, R. J., Kraft, J. M., Baranger, A., \& Coyne, C. J. (2002). Quantitative trait loci for partial resistance to Aphanomyces root rot in pea. Theoretical and Applied Genetics, 106, 28-39.

Pilet-Nayel, M. L., Muehlbauer, F. J., McGee, R. J., Kraft, J. M., Baranger, A., $\&$ Coyne, C. J. (2005). Consistent quantitative trait loci in pea for partial resistance to Aphanomyces euteiches isolates from the United States and France. Phytopathology, 95, 1287-1293.

Prashar, P., \& Vandenberg, A. (2017). Genotype-specific responses to the effects of commercial Trichoderma formulations in lentil (Lens culinaris ssp. culinaris) in the presence and absence of the oomycete pathogen Aphanomyces euteiches. Biocontrol Science and Technology, 27, 1123-1144.

Preisig, C. L., Bell, J. N., Sun, Y., Hrazdina, G., Matthews, D. E., \& Vanetten, H. D. (1990). Biosynthesis of the phytoalexin pisatin. Plant Physiology, 94, 1444-1448.

Prioul, S., Deniot, G., Morin, G., Frankewitz, A., \& Baranger, A. (2004). Mapping of quantitative trait loci for partial resistance to Mycosphaerella pinodes in pea (Pisum sativum L.), at the seedling and adult plant stages. Theoretical and Applied Genetics, 108, 1322-1334.

Pumphrey, G. M., \& Madsen, E. L. (2008). Field-based stable isotope probing reveals the identities of benzoic acid-metabolizing microorganisms and their in situ growth in agricultural soil. Applied and Environmental Microbiology, 74, 4111-4118.

Ramalingam, A., Kudapa, H., Pazhamala, L. T., Weckwerth, W., \& Varshney, R. K. (2015). Proteomics and Metabolomics: Two Emerging Areas for Legume Improvement. Frontiers in Plant Science, 6, 1116.

Rashid, K. Y., \& Bernier, C. C. (1993). Genetic diversity among isolates of Rhizoctonia solani and sources of resistance in Vicia faba. Canadian Journal of Plant Pathology, 15, 23-28.

Raza, S., Christiansen, J. L., Jørnsgård, B., \& Ortiz, R. (2000). Partial resistance to a Fusarium root disease in Egyptian white lupin landraces. Euphytica, 112, 233-237.

Reckling, M., Bergkvist, G., Watson, C. A., Stoddard, F. L., Zander, P. M., Walker, R. L., ... Bachinger, J. (2016). Trade-offs between economic and environmental impacts of introducing legumes into cropping systems. Frontiers in Plant Science, 7, 1-15.

Ren, L., Zhang, N., Wu, P., Huo, H., Xu, G., \& Wu, G. (2015). Arbuscular mycorrhizal colonization alleviates Fusarium wilt in watermelon and modulates the composition of root exudates. Plant Growth Regulation, 77, 77-85.
Rose, T. J., Damon, P., \& Rengel, Z. (2010). Phosphorus-efficient faba bean (Vicia faba L.) genotypes enhance subsequent wheat crop growth in an acid and an alkaline soil. Crop \& Pasture Science, 61, 1009

Roskothen, P. (1989). Genetic effects on host $\times$ strain interaction in the symbiosis of Vicia faba and Rhizobium leguminosarum. Plant Breeding, 102, 122-133.

Rossman, D. R., Rojas, A., Jacobs, J. L., Mukankusi, C., Kelly, J. D., \& Chilvers, M. I. (2017). Pathogenicity and virulence of soilborne oomycetes on Phaseolus vulgaris. Plant Disease, 101, 1851-1859.

Ruan, Y., Kotraiah, V., \& Straney, D. (1995). Flavonoids stimulate spore germination in Fusarium solani pathogenic on legumes in a manner sensitive to inhibitors of cAMP-dependent protein kinase. Molecular Plant-Microbe Interactions, 8, 929.

Rubiales, D., Fondevilla, S., Chen, W., Gentzbittel, L., Higgins, T. J. V. V., Castillejo, M. A., ... Rispail, N. (2015). Achievements and challenges in legume breeding for pest and disease resistance. Critical Reviews in Plant Sciences, 34, 195-236.

Rubiales, D., \& Mikic, A. (2014). Introduction: Legumes in sustainable agriculture. Critical Reviews in Plant Sciences, 34, 2-3.

Rudrappa, T., Czymmek, K. J., Paré, P. W., \& Bais, H. P. (2008). Rootsecreted malic acid recruits beneficial. Plant Physiology, 148, 15471556.

Russell, G. E. (1978). The control of pests and diseases. In Plant breeding for pest and disease resistance (pp. 3-14). Elsevier Ltd.

Rybakova, D., Cernava, T., Köberl, M., Liebminger, S., Etemadi, M., \& Berg G. (2016). Endophytes-assisted biocontrol: novel insights in ecology and the mode of action of Paenibacillus. Plant and Soil, 405, 125-140.

Sandal, N., Petersen, T. R., Murray, J., Umehara, Y., Karas, B., Yano, K., ... Stougaard, J. (2006). Genetics of symbiosis in Lotus japonicus: Recombinant inbred lines, comparative genetic maps, and map position of 35 symbiotic loci. Molecular Plant-Microbe Interactions, 19, 80-91.

Schmutz, J., McClean, P. E., Mamidi, S., Wu, G. A., Cannon, S. B., Grimwood, J., ... Jackson, S. A. (2014). A reference genome for common bean and genome-wide analysis of dual domestications. Nature Genetics, 46, 707-713.

Schneider, K. A., Grafton, K. F., \& Kelly, J. D. (2001). QTL analysis of resistance to Fusarium root rot in bean. Crop Science, 41, 535-542.

Shang, H., Grau, C. R., \& Peters, R. D. (2000). Oospore germination of Aphanomyces euteiches in root exudates and on the rhizoplanes of crop plants. Plant Disease, 84, 994-998.

Sharma S.B., Sikora R.A., Greco N., Di Vito M. \& Caubel G. (1994). Screening techniques and sources of resistance to nematodes in cool season food legumes. Euphytica 73, 59-66.

Shcherbakova, E. N., Shcherbakov, A. V., Andronov, E. E., Gonchar, L. N., Kalenskaya, S. M., \& Chebotar, V. K. (2017). Combined pre-seed treatment with microbial inoculants and Mo nanoparticles changes composition of root exudates and rhizosphere microbiome structure of chickpea (Cicer arientinum L.) plants. Symbiosis, 73, 57-69.

Shehata, M. A., Davis, D. W., \& Anderson, N. A. (1981). Screening peas for resistance to stem rot caused by Rhizoctonia solani. Plant Disease, 65 , 417-419.

Shoresh, M., Harman, G. E., \& Mastouri, F. (2010). Induced systemic resistance and plant responses to fungal biocontrol agents. Annual Review of Phytopathology, 48, 21-43.

Shtark, O. Y., Borisov, A. Y., Zhukov, V. A., \& Tikhonovich, I. A. (2012). Mutually beneficial legume symbioses with soil microbes and their potential for plant production. Symbiosis, 58, 51-62.

Silbernagel, M. J. (1990). Genetic and cultural control of Fusarium root rot in bush snap beans. Plant Disease, 74, 61-66.

Sillero, J. C., Villegas-Fernández, A. M., Thomas, J., Rojas-Molina, M. M., Emeran, A. A., Fernández-Aparicio, M., \& Rubiales, D. (2010). Faba bean breeding for disease resistance. Field Crops Research, 115, 297-307.

Sindhu, S. S., Dua, S., Verma, M. K., \& Khandelwal, A. (2010). Growth promotion of legumes by inoculation of rhizosphere bacteria. In M. S. 
Khan (Ed.), Microbes for legume improvement (pp. 195-235). Wien: Springer-Verlag.

Singh, U. P., Prithiviraj, B., Singh, K. P., \& Sarma, B. K. (2000). Control of powdery mildew (Erysiphe pisi) of pea (Pisum sativum) by combined application of plant growth-promoting rhizobacteria and Neemazal. Journal of Plant Diseases and Protection, 107, 59-66.

Šišić, A., Baćanović, J., \& Finckh, M. R. (2017). Endophytic Fusarium equiseti stimulates plant growth and reduces root rot disease of pea (Pisum sativum L.) caused by Fusarium avenaceum and Peyronellaea pinodella. European Journal of Plant Pathology, 148, 271-282.

Smith, K. P., \& Goodman, R. M. (1999). Host variation for interactions with beneficial plant-associated microbes. Annual Review of Phytopathology, 37, 476-491.

Smith, K. P., Handelsman, J., \& Goodman, R. M. (1999). Genetic basis in plants for interactions with disease-suppressive bacteria. Proceedings of the National Academy of Sciences, 96, 4786-4790.

Soby, S., Caldera, S., Bates, R., \& VanEtten, H. (1996). Detoxification of the phytoalexins maackiain and medicarpin by fungal pathogens of alfalfa. Phytochemistry, 41, 759-765.

Steinkellner, S., Hage-Ahmed, K., García-Garrido, J. M., Illana, A., Ocampo, J. A., \& Vierheilig, H. (2012). A comparison of wild-type, old and modern tomato cultivars in the interaction with the arbuscular mycorrhizal fungus Glomus mosseae and the tomato pathogen Fusarium oxysporum f. sp. lycopersici. Mycorrhiza, 22, 189-194.

Stevenson, P. C., Padgham, D. E., \& Haware, M. P. (1995). Root exudates associated with the resistance of four chickpea cultivars (Cicer arietinum) to two races of Fusarium oxysporum f.sp. ciceri. Plant Pathology, 44, 686-694.

Subbarao, G. V., Ae, N., \& Otani, T. (1997). Genotypic variation in iron-, and aluminum-phosphate solubilizing activity of pigeonpea root exudates under P deficient conditions. Soil Science \& Plant Nutrition, 43, 295-305.

Sugiyama, A., \& Yazaki, K. (2012). Root exudates of legume plants and their involvement in interactions with soil microbes. In Secretions and exudates in biological systems, signaling and communication in plants (pp. 27-49).

Suo, B., Chen, Q., Wu, W., Wu, D., Tian, M., Jie, Y., ... Wen, J. (2016). Chemotactic responses of Phytophthora sojae zoospores to amino acids and sugars in root exudates. Journal of General Plant Pathology, 82, 142-148.

Taheri, E. A., Chatterton, S., Foroud, N. A., Gossen, B. D., McLaren, D. L., Esmaeili Taheri, A., ... McLaren, D. L. (2017). Identification and community dynamics of fungi associated with root, crown, and foot rot of field pea in western Canada. European Journal of Plant Pathology, 147, 489-500.

Talekar, S. C., Lohithaswa, H. C., \& Viswanatha, K. P. (2017). Identification of resistant sources and DNA markers linked to genomic region conferring dry root rot resistance in chickpea (Cicer arietinum L.). Plant Breeding, 136, 161-166.

Tarafdar, J. C., \& Rao, A. V. (1997). Response of arid legumes to VAM fungal inoculation. Symbiosis, 22, 265-274.

Taschen, E., Amenc, L., Tournier, E., Deleporte, P., Malagoli, P., Fustec, J., ... Bernard, L. (2017). Cereal-legume intercropping modifies the dynamics of the active rhizospheric bacterial community. Rhizosphere, 3, 191-195.

Thomma, B., Cammue, B., \& Thevissen, K. (2002). Plant defensins. Planta, 216, 193-202.

Toghueo, R. M. K., Eke, P., Zabalgogeazcoa, Í., de Aldana, B. R. V., Nana, L. W., \& Boyom, F. F. (2016). Biocontrol and growth enhancement potential of two endophytic Trichoderma spp. from Terminalia catappa against the causative agent of common bean root rot (Fusarium solani). Biological Control, 96, 8-20.

Toju, H., Sato, H., Yamamoto, S., Kadowaki, K., Tanabe, A. S., Yazawa, S., ... Agata, K. (2013). How are plant and fungal communities linked to each other in belowground ecosystems? A massively parallel pyrosequencing analysis of the association specificity of root-associated fungi and their host plants. Ecology and Evolution, 3, 3112-3124.

Tran, H. S., You, M. P., Khan, T. N., \& Barbetti, M. J. (2016). Pea black spot disease complex on field pea: Dissecting the roles of the different pathogens in causing epicotyl and root disease. European Journal of Plant Pathology, 144, 595-605.

Tu, J. C. (1991). Response of cultivars and breeding lines to the disease complex of fusarium wilt and root rot of green peas in southwestern Ontario. Canadian Plant Disease Survey, 71, 9-12.

Turner, T. R., James, E. K., Poole, P. S., Gilbert, J., Meyer, F., Jansson, J., ... Jones, J. (2013). The plant microbiome. Genome Biology, 14, 209.

Valverde, A., Burgos, A., Fiscella, T., Rivas, R., Velázquez, E., RodríguezBarrueco, C., ... Igual, J.-M. (2006). Differential effects of coinoculations with Pseudomonas jessenii PSO6 (a phosphate-solubilizing bacterium) and Mesorhizobium ciceri C-2/2 strains on the growth and seed yield of chickpea under greenhouse and field conditions. Plant and Soil, 287, 43-50.

Vandemark, G. J., Ariss, J. J., \& Hughes, T. J. (2010). Real-time PCR suggests that Aphanomyces euteiches is associated with reduced amounts of Phytophthora medicaginis in alfalfa that is co-inoculated with both pathogens. Journal of Phytopathology, 158, 117-124.

Vandemark, G. J., \& Porter, L. D. (2010). First report of lentil root rot caused by Aphanomyces euteiches in Idaho. Plant Disease, 94, 480-480.

Vandenkoornhuyse, P., Quaiser, A., Duhamel, M., Le Van, A., \& Dufresne, A. (2015). The importance of the microbiome of the plant holobiont. New Phytologist, 206, 1196-1206.

Verma, S., Adak, A., \& Prasanna, R. (2016). Microbial priming elicits improved plant growth promotion and nutrient uptake in pea. Israel Journal of Plant Sciences, 63, 191-207.

Wagner, M. R., Lundberg, D. S., Del Rio, T. G., Tringe, S. G., Dangl, J. L., \& Mitchell-Olds, T. (2016). Host genotype and age shape the leaf and root microbiomes of a wild perennial plant. Nature Communications, 7 , 12151.

Walker, T. S., Bais, H. P., Halligan, K. M., Stermitz, F. R., \& Vivanco, J. M. (2003). Metabolic profiling of root exudates of Arabidopsis thaliana. Journal of Agricultural and Food Chemistry, 51, 2548-2554.

Waltz, E. (2017). A new crop of microbe startups raises big bucks, takes on the establishment. Nature Biotechnology, 35, 1120-1122.

Wang, C., Zheng, M., Song, W., Wen, S., Wang, B., Zhu, C., \& Shen, R. (2017). Impact of 25 years of inorganic fertilization on diazotrophic abundance and community structure in an acidic soil in southern China. Soil Biology and Biochemistry, 113, 240-249.

Wang, G. Z., Li, H. G., Christie, P., Zhang, F. S., Zhang, J. L., \& Bever, J. D. (2017). Plant-soil feedback contributes to intercropping overyielding by reducing the negative effect of take-all on wheat and compensating the growth of faba bean. Plant and Soil, 415, 1-12.

Wang, H., Chang, K. F., Hwang, S. F., Gossen, B. D., Turnbull, G. D., Howard, R. J., \& Strelkov, S. E. (2006). Response of lentil cultivars to rhizoctonia seedling diseases in Canada. Journal of Plant Diseases and Protection, 113, 219-223.

Watson, A., Browne, S. L., Snudden, M. G., \& Mudford, E. M. (2013). Aphanomyces root rot of beans and control options. Australasian Plant Pathology, 42, 321-327.

Weeden, N. F., McGee, R., Grau, C. R., \& Muehlbauer, F. J. (2000). A gene influencing tolerance to common root rot is located on linkage group IV. Pisum Genetics, 32, 53-55.

Weinert, N., Piceno, Y., Ding, G. C., Meincke, R., Heuer, H., Berg, G., ... Smalla, K. (2011). PhyloChip hybridization uncovered an enormous bacterial diversity in the rhizosphere of different potato cultivars: Many common and few cultivar-dependent taxa. FEMS Microbiology Ecology, 75, 497-506.

Wen, X., Wang, M., Ti, J., Wu, Y., \& Chen, F. (2017). Bacterial community composition in the rhizosphere of maize cultivars widely grown in different decades. Biology and Fertility of Soils, 53, 221-229. 
Whalley, W. M., \& Taylor, G. S. (1973). Influence of pea-root exudates on germination of conidia and chlamydospores of physiologic races of Fusarium oxysporum f. pisi. Annals of Applied Biology, 73, 269-276.

Wicker, E., Moussart, A., Duparque, M., \& Rouxel, F. (2003). Further contributions to the development of a differential set of pea cultivars (Pisum sativum) to investigate the virulence of isolates of Aphanomyces euteiches. European Journal of Plant Pathology, 109, 47-60.

Wilbois, K.-P., Böhm, H., Bohne, B., Brandhuber, R., Bruns, C., Demmel, M., ... Wolf, D. (2013). Steigerung der Wertschöpfung ökologisch angebauter Marktfrüchte durch Optimierung des Managements der Bodenfruchtbarkeit. Frankfurt am Main.

Wissuwa, M., Mazzola, M., \& Picard, C. (2009). Novel approaches in plant breeding for rhizosphere-related traits. Plant and Soil, 321, 409-430.

Wouterlood, M., Cawthray, G. R., Turner, S., Lambers, H., \& Veneklaas, E. J. (2004). Rhizosphere carboxylate concentrations of chickpea are affected by genotype and soil type. Plant and Soil, 261, 1-10.

Wu, H., Wu, L., Zhu, Q., Wang, J., Qin, X., Xu, J., ... Lin, W. (2017). The role of organic acids on microbial deterioration in the Radix pseudostellariae rhizosphere under continuous monoculture regimes. Scientific Reports, 7, 1-13.

Xu, L., Ravnskov, S., Larsen, J., \& Nicolaisen, M. (2012). Linking fungal communities in roots, rhizosphere, and soil to the health status of Pisum sativum. FEMS Microbiology Ecology, 82, 736-745.

Xue, A. G. (2003). Biological control of pathogens causing root rot complex in field pea using Clonostachys rosea Strain ACM941. Phytopathology, 93, 329-335.

Yang, C., Bueckert, R., Schoenau, J., Diederichsen, A., Zakeri, H., \& Warkentin, T. (2017). Symbiosis of selected Rhizobium leguminosarum bv. viciae strains with diverse pea genotypes: Effects on biological nitrogen fixation. Canadian Journal of Microbiology, 63, 909-919.

Yu, L., Nicolaisen, M., Larsen, J., \& Ravnskov, S. (2012). Molecular characterization of root-associated fungal communities in relation to health status of Pisum sativum using barcoded pyrosequencing. Plant and Soil, 357, 395-405.

Yuan, J., Chaparro, J. M., Manter, D. K., Zhang, R., Vivanco, J. M., \& Shen, Q. (2015). Roots from distinct plant developmental stages are capable of rapidly selecting their own microbiome without the influence of environmental and soil edaphic factors. Soil Biology and Biochemistry, 89, 206-209.
Zachow, C., Müller, H., Tilcher, R., \& Berg, G. (2014). Differences between the rhizosphere microbiome of Beta vulgaris ssp. maritimaancestor of all beet crops-and modern sugar beets. Frontiers in Microbiology, 5, 415.

Zancarini, A., Mougel, C., Terrat, S., Salon, C., \& Munier-Jolain, N. (2013). Combining ecophysiological and microbial ecological approaches to study the relationship between Medicago truncatula genotypes and their associated rhizosphere bacterial communities. Plant and Soil, 365, 183-199.

Zander, P., Amjath-Babu, T. S., Preissel, S., Reckling, M., Bues, A., Schläfke, N., ... Watson, C. (2016). Grain legume decline and potential recovery in European agriculture: a review. Agronomy for Sustainable Development, 36, 26.

Zhang, A., Sun, H., Wang, P., Han, Y., \& Wang, X. (2012). Modern analytical techniques in metabolomics analysis. The Analyst, 137, 293-300.

Zhang, F., Meng, X., Yang, X., Ran, W., \& Shen, Q. (2014). Quantification and role of organic acids in cucumber root exudates in Trichoderma harzianum T-E5 colonization. Plant Physiology and Biochemistry, 83, 250-257.

Zhang, H., Wang, R., Chen, S., Qi, G., He, Z., \& Zhao, X. (2017). Microbial taxa and functional genes shift in degraded soil with bacterial wilt. Scientific Reports, 7, 1-11.

Zhang, N., Wang, D., Liu, Y., Li, S., Shen, Q., \& Zhang, R. (2014). Effects of different plant root exudates and their organic acid components on chemotaxis, biofilm formation and colonization by beneficial rhizosphere-associated bacterial strains. Plant and Soil, 374, 689-700.

Zhang, Y., Ruyter-Spira, C., \& Bouwmeester, H. J. (2015). Engineering the plant rhizosphere. Current Opinion in Biotechnology, 32, 136-142.

Zuiderveen, G. H., Padder, B. A., Kamfwa, K., Song, Q., \& Kelly, J. D. (2016). Genome-wide association study of anthracnose resistance in andean beans (Phaseolus vulgaris). PLoS One, 11, e0156391.

How to cite this article: Wille L, Messmer MM, Studer B, Hohmann P. Insights to plant-microbe interactions provide opportunities to improve resistance breeding against root diseases in grain legumes. Plant Cell Environ. 2019;42:20-40. https://doi.org/10.1111/pce.13214 